\title{
From Rebellion to Electoral Violence: Evidence from Burundi
}

\author{
ANDREA COLOMBO \\ European Centre for Advanced Research in Economics and Statistics (ECARES), \\ Université libre de Bruxelles
}

OLIVIA D'AOUST

World Bank

OLIVIER STERCK

Centre for the Study of African Economies (CSAE), University of Oxford

\section{Introduction}

\begin{abstract}
Democratic governance-by protecting minorities, encouraging political pluralism, and upholding the rule of law-can channel internal dissent peacefully, and thus help avert civil wars. Conversely, authoritarian and highly personalized forms of governance, ethnic discrimination, human rights violations, and corruption are among the root causes of many of today's internal conflicts. (UN Secretary-General Kofi Annan) ${ }^{1}$
\end{abstract}

Promoting democratization and elections has been at the core of peacebuilding missions in postconflict societies since the end of the Cold War. Early postwar elections are indeed expected to increase legitimacy and accountability

We thank Amatora Mu Mahoro Ushahidi, the International Foundation for Electoral Systems, and Hélène Helbig de Balzac for the data on electoral violence. We also acknowledge the kind institutional collaboration of the Afrobarometer. We are grateful to the following for useful comments and discussions: Stéphane Baele, Tom Bundervoet, Katarzyna Cieslik, Paul Collier, Catherine Dehon, Bram De Rock, Antonio Estache, James Fenske, Renaud Foucart, Marjorie Gassner, Victor Ginsburgh, Anke Hoeffler, Eliana La Ferrara, Nastassia Leszczynska, Edward Miguel, Nathan Nunn, Davy Paindaveine, Jean-Philippe Platteau, Cyrus Samii, Philip Verwimp, three anonymous referees, and participants at the 2014 Advanced Graduate Workshop on Poverty, Development, and Globalization, CSAE, International Economic Association, Nordic Conference in Development Economics, and Summer School in Development Economics (SSDev) conferences and the ECARES internal seminar, Université libre de Bruxelles, the University of California at Berkeley Political Economy Research and Development lunches, and the CSAE research workshop. Olivia D'Aoust acknowledges financial support from the Fonds National de la Recherche Scientifique. Any remaining errors are our own. Contact the corresponding author, Andrea Colombo, at andrea.colombo@ulb.be.

${ }^{1}$ From the address delivered by Annan at the 2000 international conference "Towards a Community of Democracies" in Warsaw.

Electronically published January 14, 2019

(c) 2019 by The University of Chicago. All rights reserved. 0013-0079/2019/6702-0004\$10.00 
of the newly elected governments and foster social trust in war-torn societies, thus contributing to long-lasting peace and sustainable development. Nonetheless, elections have failed to be properly implemented in a vast majority of countries in Africa. From 1975 to 2011, no less than 80\% of African polls were disturbed by violence, bribery, intimidation, or inequitable government interference, compared to $40 \%$ in non-African countries (Bishop and Hoeffler 2014). Developing a better understanding of the causes of failed elections is all the more important in view of their devastating effects on the living conditions of civilians. Furthermore, failed elections undermine the legitimacy of the states, destroy social capital, and result in poor economic and political performance, which can ultimately plunge fragile countries back into war. ${ }^{2}$

In which context is electoral violence likely to emerge? This paper tests three hypotheses that have already been discussed in the literature on civil conflict but never tested simultaneously in the context of electoral violence: (1) ethnic composition and ethnic grievances, (2) political competition, and (3) the presence and distribution of specialists in violence.

First, a vast literature has studied how ethnic grievances may foster violence and affect the provision of public goods (see, e.g., Easterly and Levine 1997; Alesina, Baqir, and Easterly 1999; Garcia-Montalvo and Reynal-Querol 2005a). Popular resentment is likely to be exacerbated during electoral periods as elites have been shown to exploit ethnic allegiances to seize political power (Eifert, Miguel, and Posner 2010). Second, economists have shown theoretically that violent campaigning may be an optimal strategy for political actors, depending on their position (incumbent vs. opponent) and their relative support among the population (Ellman and Wantchekon 2000; Chaturvedi 2005; Robinson and Torvik 2009; Collier and Vicente 2012). According to theory, violence is more likely to occur when political competition is intense, such that intimidation and electoral violence can reverse electoral outcomes. Third, the theoretical literature has emphasized the important role played by specialists in violence (Chaturvedi 2005) or hard-core supporters (Collier and Vicente 2012). In postconflict countries, demobilized combatants, whose factions often turn into political parties after civil war, are good candidates for playing such a role during electoral campaigns. As such, they might be more likely to resort to violence and rely on nondemocratic persuasion tools, hence undermining the conduct of free and fair elections. Most theoretical papers on elec-

\footnotetext{
${ }^{2}$ Electoral violence has been shown to have damaging consequences on civilians (see, e.g., Dupas and Robinson 2010, 2012; Omotola 2010), on legitimacy (Berman et al. 2014), on social capital (Dercon and Gutiérrez-Romero 2012), on economic and political consequences (Chauvet and Collier 2009; Kudamatsu 2012; Collier and Hoeffler 2015), and on relapse into conflict (Henderson and Singer 2000; Hegre et al. 2001; Brancati and Snyder 2012).
} 
toral violence have illustrated interesting case studies, but none had undertaken rigorous empirical analysis to test its predictions.

We test these three hypotheses in the context of the 2010 electoral cycle in Burundi. These elections were organized in a very volatile and dangerous political context. This constraint and the nature of our research question made a randomized controlled trial virtually impossible. Our study exploits a unique data set that combines information at the municipal level on electoral violence, ethnic composition, electoral results, and the affiliation and distribution of demobilized rebels who fought during the 1993-2009 civil war. In line with the conflict literature, we use and compare different indexes of fractionalization and polarization. ${ }^{3}$ The identification strategy exploits variations between neighboring municipalities, relying on the fact that these are more likely to have similar unobserved characteristics.

Three important conclusions can be drawn from our empirical analysis. First, ethnic grievances, while traditionally indicated as one of the main drivers of violence, are not significantly related to the incidence of electoral violence in 2010. Instead, electoral violence was higher in municipalities hosting a larger proportion of Hutu. Second, political competition between parties is a strong predictor of electoral violence. An increase of 1 standard deviation in political fractionalization leads to an increase in violent events ranging between $27 \%$ and $45 \%$, depending on the specification. This relationship is stronger in places with numerous demobilized rebels: for political competition to turn violent, the presence of local perpetrators is necessary. Last, we find that polarization between former rebel groups is associated with more electoral violence. An increase of 1 standard deviation in polarization among rebel groups leads to an increase in violent events ranging between $43 \%$ and $52 \%$, depending on the specification. Namely, going from the lowest polarized municipality in Burundi to the highest leads to a four-fold increase in the incidence of violent events. Overall, the causes of tensions and violence in Burundi have evolved from an interethnic to an intra-Hutu rivalry between former rebel groups and political parties that are competing for power. These results are robust to a variety of estimation strategies.

Our paper contributes to three strands in the literature. First, we complement the few empirical studies on electoral violence. Focusing on the 2007 elections in Kenya, Dercon and Gutiérrez-Romero (2012) find that violence

\footnotetext{
${ }^{3}$ Fractionalization measures the probability that two individuals drawn at random from a community belong to two different groups. It is high in the presence of many groups of similar size. Polarization measures the distance of a particular distribution of groups from a bimodal distribution. It is high in the presence of two groups of similar size.
} 
emerged in areas prone to land disputes and with politically connected gangs. In the same context, Gutiérrez-Romero (2012, abstract) find that political parties had engaged in vote buying in areas where they were less likely to win, in order "to weaken the support of their political rivals and to mobilize their own." Collier and Vicente (2014) evaluate a randomized antiviolence community campaign in Nigeria. They find that the intervention decreased the intensity of violence and increased voter turnout. Fafchamps and Vicente (2013) further show that the effects of the campaign were also transmitted indirectly through kinship and geographical proximity. Developing a better understanding of the causes of electoral violence should help in the design and targeting of antiviolence campaigns.

Second, our analysis contributes to the large literature studying how polarization and fractionalization between groups can foster conflict. ${ }^{4}$ The explanatory power of fractionalization and polarization indexes have been compared in a few studies examining the link between ethnic distribution and conflict (Garcia-Montalvo and Reynal-Querol 2005a, 2005b; Schneider and Wiesehomeier 2008; Esteban, Mayoral, and Ray 2012a). To our knowledge, this paper is the first to use fractionalization and polarization indexes to capture tensions between former rebel groups. It is also the first to jointly test whether electoral violence is affected by the relative distribution of ethnic groups, political parties, and hard-core supporters.

Finally, our study also contributes to the body of research that assesses the effectiveness of demobilization programs in postconflict societies (Humphreys and Weinstein 2007; Verwimp and Bundervoet 2009; Gilligan, Mvukiyehe, and Samii 2013; D'Aoust, Sterck, and Verwimp 2016). Our paper is the first empirical study that evaluates the impact of ex-combatants' demobilization on the occurrence of violence.

In addition to these contributions, we emphasize the importance of understanding the causes of violence in Burundi. The history of the Great Lake region has shown that political instability in one country of the region may destabilize the whole area, with dramatic effects on the civilian population (Prunier 2009). Like its neighbors, Rwanda and the Democratic Republic of the Congo (DRC), Burundi has been plagued by violence and tensions between the Tutsi minority and the Hutu majority since its independence. As a matter of fact, the 1993 elections in Burundi-the first to be organized after a long Tutsi-led dictatorship—resulted in the assassination of the newly elected

\footnotetext{
${ }^{4}$ See Esteban and Ray (2008), Schneider and Wiesehomeier (2008), and Blattman and Miguel (2010) for reviews of the literature and Esteban and Ray $(2008,2011)$ for recent models comparing fractionalization and polarization indexes.
} 
Hutu president by Tutsi officers during an attempted coup. The assassination triggered a long-lasting civil war, leading to around 300,000 deaths, mostly civilian, and about 800,000 refugees, who fled the DRC, Rwanda, and Tanzania. In the Eastern provinces of the DRC, refugee camps became military bases. These events exacerbated tensions in the Great Lake region, paving the way for the Rwandan genocide and the Second Congo War (Mamdani 2001; Lemarchand 2009). The 2010 polls were the first to be organized after the civil war and the demobilization of all rebel groups in Burundi. During the writing of this paper, violence erupted in prelude to the 2015 elections, leading to hundreds of deaths and thousands of refugees, highlighting once again the importance of unveiling the mechanisms of electoral violence.

The paper is organized as follows. The history of Burundi and the context of the 2010 elections are introduced in Section II. In Section III, we lay out and justify research hypotheses by referring to the theoretical literature on conflict and electoral violence. Section IV describes the data set and the econometric methods used in the empirical analysis. Results are presented in Section V and are discussed in Section VI. Section VII concludes the study.

\section{Historical Background}

Since its independence from Belgium in 1961, the political situation in Burundi has been unstable and disrupted by recurrent episodes of violence between the country's two major ethnic groups, the Hutu majority and the Tutsi minority. ${ }^{5}$ After a short democratic transition, a group of Tutsi officers seized power in 1966 following contested elections won by the Hutu majority. From 1966 to 1988, three Tutsi presidents from the same party and the same village in the Southwestern province of Bururi governed the country and violently repressed any Hutu rebellion. ${ }^{6}$

In 1988, a democratization process was initiated under pressure from the international community. A new constitution introduced multiparty competition after 20 years of Tutsi regime. Melchior Ndadaye, from the Hutu-based party FRODEBU, triumphed in the 1993 elections and set up a government of power sharing. ${ }^{7}$ His assassination a few months later by Tutsi officers and the death of the ad interim president, Cyprien Ntaryamira, in a 1994 plane

\footnotetext{
${ }^{5}$ According to the 2012 Afrobarometer survey, the Hutu and the Tutsi represented $82 \%$ and $17 \%$ of the population, respectively. A third group, the Twa, was reported to account for less than $1 \%$ of the population.

${ }^{6}$ The three Tutsi presidents belonged to the Union for National Progress (Union pour le Progrès National, or UPRONA).

${ }^{7}$ FRODEBU is the abbreviation for the Front for Democracy in Burundi (Front pour la Démocratie du Burundi).
} 
crash in Rwanda triggered a civil war opposing the Tutsi-controlled army and radical Hutu groups. ${ }^{8}$ The already-doomed democratization process was definitely buried in July 1996 when the Tutsi-controlled army led by Pierre Buyoya, the former Tutsi president, overthrew the power-sharing government.

A fragile peace was reached through the Arusha Peace and Reconciliation Agreement on August 28, 2000. The Arusha agreements institutionalized power sharing across ethnic groups by designing an ethnically mixed transitional government and imposing ethnic quotas in institutions and political parties. ${ }^{9}$ However, the two largest Hutu rebel groups, the CNDD-FDD and the FNL-Palipehutu, rejected the peace accords and continued to fight the transitional government. ${ }^{10}$ The CNDD-FDD eventually signed a Comprehensive Ceasefire Agreement in 2003 and joined the power-sharing government. Combatants from the Burundian Armed Forces (Forces Armées Burundaise, or $\mathrm{FAB}$ ) and from the CNDD-FDD were selected to form the new national army, National Defense Force (Forces de Défense Nationale, or FDN). Those who did not fulfill selection criteria based on age, health status, and experience were demobilized according to the Disarmament, Demobilization and Reinsertion (DDR) program. Approximately 23,000 units from both sides (almost three demobilized soldiers per 1,000 inhabitants) benefited from a sequence of reinsertion and reintegration grants in order to be able "to return to their community and to sustain themselves and their families for a limited period following demobilization" (World Bank Group 2004, 11).

The CNDD-FDD won the elections held in 2005, and its leader, Pierre Nkurunziza, became president. Despite the appointment of a Hutu exponent as head of the country, the FNL-Palipehutu continued to fight the government, definitively transforming what had been an interethnic war into an intra-Hutu struggle for power. ${ }^{11}$ After a first attempt at a cease-fire agreement in 2006, the FNL-Palipehutu finally agreed to give up its weapons and turned

${ }^{8}$ The airplane carrying Burundian President Cyprien Ntaryamira and Rwandan counterpart Juvénal Habyarimana was shot down as it prepared to land in Kigali on April 6, 1994. This attack triggered the Rwandan genocide.

${ }^{9}$ According to Vandeginiste $(2015,632)$, "as much as political elites stirred and instrumentalized ethnic antagonism during the violent conflict, growing inter-elite trust and socialization in the atmosphere of the post-conflict 'spirit of Arusha' trickled down beyond formal state institutions as a driver of political and social reconciliation." In line with the Arusha agreements, the 2005 constitution guarantees 60/40 representation of Hutu and Tutsi ethnic groups in Parliament, in the government, and in the local administration and 50/50 representation in the army. The president must appoint two vice presidents, one Hutu and the other Tutsi.

${ }^{10}$ CNDD-FDD stands for the National Council for the Defense of Democracy-Forces for the Defense of Democracy (Conseil National de Défense de la Démocratie-Forces de Défense de la Démocratie); FNL-Palipehutu is the National Forces of Liberation (Forces Nationales de Libération). ${ }^{11}$ See, e.g., International Crisis Group (2011), Vandeginste (2011, 2012, 2014), and Palmans (2012). 
into a political party in 2009. Minor administrative posts were attributed to the FNL leadership. As for the CNDD-FDD, 4 year earlier, its combatants either joined the national army or benefited from the DDR program.

Elections were scheduled in 2010, only a few months after the epilogue of the civil war. Five consecutive ballots were organized, starting with the election of municipal representatives on May 24, 2010, followed by the presidential election on June 28 , the parliamentary and senatorial elections at the end of July, and ending with the election of the hills' representatives in early September. Even if several opposition parties seemed confident in their success, the FNL party was seen as the most serious opposition to the CNDD-FDD of the incumbent president, Nkurunziza (International Crisis Group 2011). Table 1 displays the names of the main parties, their creation dates, their ethnic origin, their results at the 2010 municipal election, and, for ex-rebels groups, their number of demobilized rebels.

The pre-electoral climate was spoiled by numerous violent episodes, claims of intimidation, and suspicions of fraud. In such a context, the CNDD-FDD party won the first municipal ballot outright, capturing $64 \%$ of the votes and $62 \%$ of the seats in municipal assemblies. The FNL ended up as the secondlargest force, with only $14 \%$ of the votes. FRODEBU and UPRONA ob-

TABLE 1

PARTIES AND EX-REBEL GROUPS

\begin{tabular}{|c|c|c|c|c|c|c|}
\hline Party & $\begin{array}{l}\text { Year of } \\
\text { Creation }\end{array}$ & $\begin{array}{l}\text { Ethnicity } \\
\text { of Leader }\end{array}$ & $\begin{array}{l}\text { Percentage } \\
\text { of Votes in } \\
2010\end{array}$ & $\begin{array}{c}\text { Ex-Rebel } \\
\text { Group }\end{array}$ & $\begin{array}{c}\text { Number of } \\
\text { Demobilized } \\
(\%)\end{array}$ & $\begin{array}{c}\text { Correlation Votes } \\
\text { and Share } \\
\text { Demobilized }\end{array}$ \\
\hline CNDD-FDD & 1998 & Hutu & 64.03 & Yes & $6,874(39)$ & .59 \\
\hline FNL & 1999 & Hutu & 14.15 & Yes & $6,029(34.2)$ & .57 \\
\hline UPRONA & 1957 & Tutsi & 6.25 & No & & \\
\hline FRODEBU & 1986 & Hutu & 5.43 & No & & \\
\hline MSD & 2009 & Tutsi & 3.75 & No & & \\
\hline UPD & 2003 & Hutu & 2.21 & No & & \\
\hline FRODEBU-Nyakuri & 2008 & Hutu & 1.36 & No & & \\
\hline CNDD & 1994 & Hutu & 1.26 & Yes & $1,372(7.8)$ & .76 \\
\hline MRC & 2001 & Tutsi & .62 & No & & \\
\hline PALIPE-Agakiza & 1980 & Hutu & .24 & Yes & $578(3.3)$ & .02 \\
\hline FROLINA & 1990 & Hutu & .20 & Yes & $540(3.1)$ & .31 \\
\hline KAZE-FDD & 2005 & Hutu & .00 & Yes & $361(2)$ & -.04 \\
\hline FNL dissidents & & Hutu & & Yes & $1,594(9)$ & \\
\hline FNL Icanzo & 2001 & Hutu & & Yes & $278(1.6)$ & \\
\hline
\end{tabular}

Note. CNDD-FDD = National Council for the Defense of Democracy-Forces for the Defense of Democracy; FNL = National Front for Liberation; UPRONA = Union for National Progress; FRODEBU = Front for Democracy in Burundi; MSD = Movement for Solidarity and Democracy; UPD = Union for Peace and Democracy-Zigamibanga; FRODEBU-Nyakuri = Front for Democracy in Burundi-Nyakuri; CNDD = National Council for the Defense of Democracy; MRC = Movement for the Rehabilitation of CitizensRurenzangemero; PALIPE-Agakiza $=$ Party for the Liberation of People-Agakiza; FROLINA = National Liberation Front; KAZE-FDD = Kaze-Forces for the Defense of Democracy. 
tained $5 \%$ and $6 \%$ of the votes, respectively. The international community recognized the electoral results to be free and fair. Nevertheless, the resounding defeat pushed the opposition parties to boycott the four following ballots, accusing Nkurunziza of massive fraud and irregularities (Helbig de Balzac, Ingelaere, and Vandeginste 2011; International Crisis Group 2011; Vandeginste 2012). The incumbent president, Nkurunziza, who was therefore the only candidate running for presidency, was reelected with $95 \%$ of the votes. Violence continued to be pervasive until the end of the electoral process.

The 2010 elections legitimized a quasi return to the single-party rule, with the CNDD-FDD having obtained a three-quarters majority in the National Assembly. ${ }^{12}$ The tensions that followed, however, were political, rather than ethnic, and lead to the resurgence of rebel groups-among whom were the FNL_aiming to fight the government (International Crisis Group 2012; Van Acker 2015). Many opposition leaders left the country after complaining about constant harassment and threats on their lives. Several of those who remained politically active were arrested or assassinated. Media and civil society were threatened, increasing the risk of instability and insecurity (Vandeginste 2012). In this volatile context, the country went through a new electoral round in $2015 . .^{13}$

\section{Conceptual Framework}

Our paper aims at understanding the causes of violence that perturbed the electoral process in Burundi in 2010. We test whether electoral violence was driven by (1) ethnic composition and ethnic grievances, (2) political competition, or (3) the presence and distribution of specialists in violence. This section draws on the literature on conflicts and electoral violence to explain why these channels could be relevant in triggering electoral violence in Burundi. ${ }^{14}$

\footnotetext{
${ }^{12}$ Despite the boycott, two parties decided to take part in the legislative elections in addition to the CNDD-FDD: FRODEBU-Nyakuri and UPRONA. They could send deputies to the National Assembly (Helbig de Balzac, Ingelaere, and Vandeginste 2011).

${ }^{13}$ On April 2015, the CNDD-FDD designated by the incumbent president, Nkurunziza, as its candidate for the forthcoming presidential elections, despite the fact that he had already completed the two terms in office allowed by the constitution. The announcement triggered demonstrations and violence, a failed coup d'état, and repeated delays of the elections. It should be noted, however, that the political opposition to President Nkurunziza's third mandate transcended ethnic boundaries. The plotters of the failed coup d'etat, e.g., were a Hutu and former CNDD-FDD rebel and a Tutsi and former minister of defense under President Buyoya. This anecdotal evidence reinforces a key argument of this paper: since 2005, identity politics in Burundi have unfolded along political partisanship rather than ethnic ties (Vandeginste 2015).

${ }^{14}$ The literature supports the pivotal role of these three channels in triggering electoral violence. However, the three hypotheses do not provide an exhaustive list of possible channels of electoral violence.
} 
The literature on conflict has shown that ethnic distribution is likely to be correlated with violence. As explained in the previous section, the postcolonial history of Burundi has been plagued by ethnic tensions between the Hutu and the Tutsi. This interethnic rivalry eventually triggered a bloody civil war in the nineties, partially resolved with the Arusha agreements. It is reasonable to assume that such deeply rooted ethnic cleavages survived the democratic transition and were exploited by the candidates during their electoral campaigns (Wilkinson 2004; Eifert, Miguel, and Posner 2010).

Two mechanisms could be at play. First, the theoretical literature has shown that violence is more likely to emerge if the distribution of ethnic groups is either polarized or fractionalized (Esteban and Ray 2008, 2011). The ethnic distribution is said to be polarized if there are only two groups of similar size and fractionalized if there are many groups of similar importance. Empirical evidence is mixed. While Garcia-Montalvo and Reynal-Querol (2005a, 2005b) argue that ethnic polarization best captures the likelihood of conflict, Schneider and Wiesehomeier (2008) and Esteban, Mayoral, and Ray (2012a, $2012 \mathrm{~b}$ ) find that both ethnic fractionalization and ethnic polarization are conducive to conflict, depending on the political regime and the nature of the conflict.

However, a second mechanism could also be at play. Since around $85 \%$ of the population in Burundi is of the Hutu ethnic origin, a Hutu president is expected to rule the country after the elections. ${ }^{15}$ Given the high stakes involved, electoral violence could be more likely in areas where the Hutu are the majority. This is also in line with the fact that the civil war in Burundi evolved from an interethnic conflict to an intra-Hutu struggle for power. On the contrary, Tutsi parties and Tutsi municipalities are less likely to be key in determining who would win the elections, making them less prone to engaging in violence.

We consider two indicators to capture the two mechanisms: an indicator of ethnic fractionalization and the proportion of Hutu. ${ }^{16}$ If the first mechanism prevails, ethnic fractionalization should be positively correlated with violence. If the second mechanism dominates, violence should be positively correlated with the proportion of Hutu.

We test political competition as a second potential channel of electoral violence. As explained in the historical review, the Arusha agreements institu-

\footnotetext{
${ }^{15}$ Palmans $(2012,15)$ reports that "for the majority of the population (an estimated $85 \%$ of whom are Hutu) legitimacy goes hand in hand with an ethnically representative leader."

${ }^{16}$ In the analysis, we consider only Hutu and Tutsi, implying that ethnic fractionalization and polarization indexes are proportional and, hence, perfectly multicollinear. Even if we would consider the Twa, it would not solve the multicollinearity problem as this group is marginally represented.
} 
tionalized power sharing across ethnicities and imposed ethnic quotas in political parties. The 2010 elections might, therefore, have been spoiled by intense political competition rather than by ethnic tensions. As for ethnicity, two mechanisms may be at play. On one hand, parties might engage in violence if the political context is heavily fragmented or polarized. In these situations, violence or intimidation could indeed be beneficial in gaining a small political advantage, which can ultimately be decisive for winning the elections (Sterck 2015). On the other hand, the theoretical models of Chaturvedi (2005) and Collier and Vicente (2012) conclude that violent campaigning is used by a weak party to discourage the supporters of its rival from voting. In their framework, violent campaigning increases in the initial support for the rival. These two mechanisms lead to very different predictions regarding political competition, which we measure by polarization and fractionalization indexes. If the first mechanism is stronger, political competition should be positively correlated with electoral violence. On the contrary, political competition should be negatively correlated with electoral violence if the second mechanism prevails.

As for the third channel of electoral violence examined in this paper, we study the role played by hard-core supporters of parties or specialists in violence. According to Chaturvedi (2005), Collier and Vicente (2012), and Sterck (2015), conflictual campaigning is more effective in the presence of numerous specialists in violence. In the context of postconflict Burundi, demobilized excombatants are likely to play this role. This is plausible for at least three reasons. After the civil war, most rebel groups turned into political parties, and the literature suggests that demobilized soldiers are active in the postwar political life of their country (Goose and Smyth 1994; Annan et al. 2011; Gilligan, Mvukiyehe, and Samii 2013). Demobilized ex-combatants might also be more likely to engage in violence given their past histories. Finally, in a context of widespread poverty and unemployment, they may have higher incentives to support their former leader (Human Rights Watch 2010). We therefore test whether the number and the distribution of demobilized ex-rebels is correlated with electoral violence. However, given the limitation of our data, we are not be able to determine when violence is used to gain electoral advantage and when it is the mere consequence of frustrations among demobilized rebels that are resurfacing during the elections. We measure the distribution of former combatants by using indexes of polarization and fractionalization of demobilized combatants.

While the literature agrees that the distribution of religious, ethnic, or political groups has an impact on the likelihood of conflict, it has not reached a consensus on whether conflict is the result of fractionalization or polariza- 
tion. ${ }^{17}$ In our paper, we therefore compare the predictive power of indexes of fractionalization and polarization related to political parties and demobilized rebel groups. The recent findings of Esteban and Ray (2011) and Esteban, Mayoral, and Ray (2012a, 2012b) are, however, worth emphasizing. They show, theoretically and empirically, that polarization is more conducive of violence than fractionalization "when the winners enjoy a public prize," such as political power or religious hegemony. The contrary is true when the prize is private, such as looted resources.

\section{Identification Strategy}

In order to test the three hypotheses, we estimate the following model:

$$
\begin{aligned}
& \text { violent episodes }_{m}=\alpha_{m}+\beta_{1} \text { Hutu share }{ }_{m}+\beta_{2} \text { ethnic } \text { frac }_{m} \\
& +\phi_{1} \text { political } \operatorname{pol}_{m}+\phi_{2} \text { political } \text { frac }_{m} \\
& +\gamma_{1} \text { demob rebels }^{\prime} \operatorname{pol}_{m}+\gamma_{2} \text { demob rebels }{ }^{\prime} \text { frac }_{m} \\
& +\gamma_{3} \text { number demob rebels }{ }_{m}^{\prime}+\mathbf{X}_{m}^{\prime} \delta+Z_{k}+\epsilon_{m},
\end{aligned}
$$

where violent episodes $_{m}$ is the number of episodes of electoral violence that occurred in each municipality $m \in[1,129]$. Hutu share ${ }_{m}$ and ethnic frac $_{m}$ capture the ethnic distribution between Hutu and Tutsi. Political competition is measured by fractionalization and polarization indexes based on the result of the 2010 municipal elections (political $\mathrm{frac}_{m}$ and political $\mathrm{pol}_{m}$ ). Demob rebels ${ }^{\prime}$ $\mathrm{frac}_{m}$ and demob rebels ${ }^{\prime} \mathrm{pol}_{m}$ are indexes of fractionalization and polarization between demobilized rebels at the municipal level. Number demob rebels ${ }_{m}$ captures the number of demobilized rebels who returned to the municipality per 1,000 inhabitants. We use $\mathbf{X}_{m}$ to indicate a vector of covariates that includes a median wealth index, population, population density, and past violence. ${ }^{18}$ Fixed effects are indicated by $Z_{k}$. Summary statistics are shown in table 2 .

\footnotetext{
${ }^{17}$ Most of the theoretical literature has been written by Joan Esteban and Debraj Ray (for recent examples comparing fractionalization and polarization indexes, see Esteban and Ray 2008, 2011). See, e.g., Esteban and Ray (2008), Schneider and Wiesehomeier (2008), and Blattman and Miguel (2010) for reviews of the literature. See Garcia-Montalvo and Reynal-Querol (2005a, 2005b), Schneider and Wiesehomeier (2008), and Esteban, Mayoral, and Ray (2012a, 2012b) for contradictory evidence on the effect of ethnic polarization and ethnic fractionalization on conflict.

${ }^{18}$ Past violence, population, and population density are expressed in log given their high dispersion. The indexes of ethnic, political, and ex-soldiers' fractionalization; the indexes of political and demobilized combatants' polarization; and the wealth index are standardized.
} 
TABLE 2

SUMMARY STATISTICS

\begin{tabular}{|c|c|c|c|c|c|c|}
\hline & Mean & SD & Minimum & Median & Maximum & $N$ \\
\hline Violent episodes & 4.02 & 4.52 & 0 & 3 & 21 & 129 \\
\hline \multicolumn{7}{|l|}{ Demobilized rebels: } \\
\hline Polarization & .58 & .18 & 0 & .60 & 1 & 129 \\
\hline Fractionalization & .54 & .16 & 0 & .58 & .78 & 129 \\
\hline Total number (per 1,000) & 2.13 & 2.13 & .14 & 1.43 & 12.72 & 129 \\
\hline CNDD-FDD & 53.29 & 61.08 & 0 & 35 & 350 & 129 \\
\hline CNDD & 10.64 & 35.76 & 0 & 2 & 348 & 129 \\
\hline PALIPE-Agakiza & 4.48 & 11.66 & 0 & 0 & 74 & 129 \\
\hline FROLINA & 4.19 & 20.09 & 0 & 0 & 208 & 129 \\
\hline KAZE-FDD & 2.80 & 6.23 & 0 & 1 & 58 & 129 \\
\hline FNL Icanzo & 2.16 & 8.16 & 0 & 0 & 74 & 129 \\
\hline FNL-Rwasa & 46.74 & 55.61 & 1 & 29 & 275 & 129 \\
\hline FNL dissidents & 12.36 & 37.42 & 0 & 3 & 326 & 129 \\
\hline \multicolumn{7}{|l|}{ Ethnic cleavages: } \\
\hline Hutu share & .81 & .14 & .47 & .84 & .98 & 129 \\
\hline Ethnic fractionalization & .27 & .14 & .03 & .27 & .50 & 129 \\
\hline \multicolumn{7}{|l|}{ Political competition: } \\
\hline 2010 fractionalization & .50 & .18 & .15 & .47 & .81 & 129 \\
\hline 2010 polarization & .44 & .13 & .15 & .43 & .87 & 129 \\
\hline 2005 fractionalization & .48 & .18 & .08 & .49 & .83 & 129 \\
\hline 2005 polarization & .48 & .17 & .08 & .50 & .92 & 129 \\
\hline \multicolumn{7}{|l|}{ Other covariates: } \\
\hline Median wealth index & $-15,144$ & 91,514 & $-55,170$ & $-41,004$ & 545,315 & 128 \\
\hline Total violence (1997-2009) & 20.40 & 37.68 & 0 & 9 & 357 & 129 \\
\hline Attacks on civilians (1997-2009) & 10.97 & 21.09 & 0 & 3 & 177 & 129 \\
\hline Battles (1997-2009) & 9.43 & 18.12 & 0 & 5 & 180 & 129 \\
\hline Population (2008 census) & 62,431 & 26,454 & 17,481 & 57,284 & 155,005 & 129 \\
\hline Population density & 1,235 & 4,174 & 72.34 & 352 & 33,831 & 129 \\
\hline
\end{tabular}

Note. See table 1 for abbreviations.

\section{A. Data}

1. Electoral Violence

The measure of electoral violence is constructed using the Burundi Ushahidi electoral violence data set. The Ushahidi (testimony) software was developed to map reports of violence in Kenya after the postelection fallout in 20072008. It was then adapted to the Burundian context through the Amatora mu Mahoro (Elections in Peace) project. It also draws on the Elections Violence Education and Resolution project, which gathers information on incidents of violence and peace activities and has been conducted in a dozen countries since 2003.

During the 2010 electoral process in Burundi, 450 well-vetted and trained monitors — on average, 3.5 per municipality — had to verify and provide detailed information about violent incidents. ${ }^{19}$ The procedure for reporting

${ }^{19}$ The International Foundation for Electoral Systems endorsed the Declaration of Global Principles for Non-Partisan Election Observation and Monitoring by Citizen Organizations and the Code of 
and registering such incidents involved three steps. First, election monitors witnessing a violent episode had to signal it by sending a text message to the Ushahidi platform. After receiving the text, Ushahidi agents had to call the election monitors back to obtain more information about the incident. A detailed report was then written for the Ushahidi website. Finally, election monitors were requested to submit a form with detailed information on the timing, the location, and type of incident within 1 week of the episode. ${ }^{20}$ To ensure information accuracy, incidents had to be reported by at least two different sources to be recorded in the database.

Information about physical violence, destruction of property, clashes between groups, and intimidation during the electoral cycle were recorded between April 26 and September 12, 2010. In the majority of cases, monitors had been unable to identify the perpetrator. This is particularly true for cases of murder or attempted murder $(n=67)$ and cases of destruction $(n=62)$. In 25 municipalities, no episodes of electoral violence were signaled. The dependent variable in our analysis is the total number of violent episodes that occurred at the municipal level. Descriptive statistics are presented in table 2. The geographical distribution of the total number of episodes is additionally presented in figure 1 . We do not observe evidence of spatial correlation in the dependent variable.

\section{Ethnic Cleavages}

Ethnicity is a sensitive matter. It is challenging to obtain ethnic data, either because it is no longer collected or publicly released. According to the Belgian census of 1959, three ethnic groups coexist in Burundi: the Hutu (85\%), the Tutsi (14\%), and the Twa (1\%). Data from this census is available only at the national level.

The 2012 Afrobarometer survey did, however, collect and release data on ethnicity in Burundi. The survey is representative at the province level. We thus proxy ethnic composition by taking the average proportion of Hutu at the province level. ${ }^{21}$ Descriptive statistics in table 2 show that the Afrobarometer figure for the proportion of Hutu- $81 \%$-is close to the $85 \%$ reported in the 1959 Belgian census.

Conduct for Non-Partisan Citizen Election Observers and Monitors, which require the highest ethical standards for impartiality and accuracy in the witnessing, reporting, and analysis of election processes and political environment.

${ }^{20}$ See NDI (2014) for more details on the methodology.

${ }^{21}$ The 2012 Afrobarometer survey has data available for 111 out of 129 municipalities. In each municipality, between eight and 32 individuals were interviewed. Given the low number of individuals interviewed in sampled municipalities, an indicator of ethnicity computed at the municipal level would suffer from a mismeasurement problem, leading to attenuation bias (Hausman 2001). 


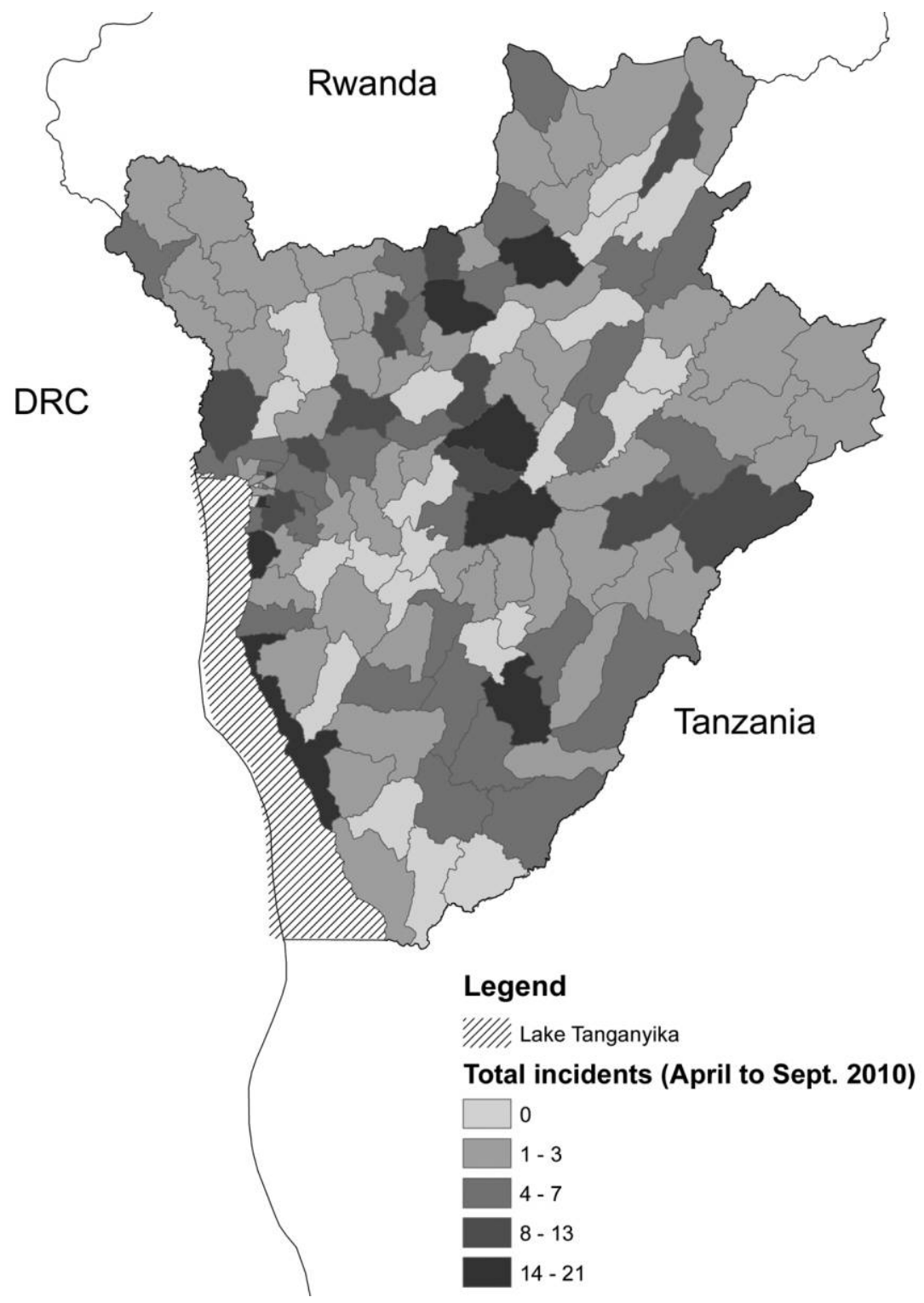

Figure 1. Distribution of electoral violence.

We use two indicators in order to capture ethnic tensions. First, we consider the proportion of Hutu itself. Second, we construct an index of ethnic fractionalization following Alesina et al. (2003):

$$
\text { ethnic fractionalization }{ }_{m}=\sum_{i=1}^{N}\left(1-\pi_{i}\right) \pi_{i}
$$


where $\pi_{i}$ is the proportion of people belonging to ethnic group $i$. The index of ethnic fractionalization can simply be interpreted as the probability that two randomly selected individuals from a given municipality belong to different ethnic groups. ${ }^{22}$

\section{Political Competition}

We construct an index of political fractionalization and an index of political polarization to capture the intensity of political competition at the municipal level. The index of political fractionalization is constructed according to equation (2) and can be interpreted as the probability that two randomly selected individuals from a given municipality had voted for a different party in the municipal elections.

For the index of political polarization, we use the index of polarization derived by Sterck (2015):

$$
\text { political polarization }{ }_{m}=1-\sum_{i=1}^{N}\left|\frac{0.5-\pi_{i}}{0.5}\right| \pi_{i}
$$

where $\pi_{i}$ is the proportion of votes obtained by each party. ${ }^{23}$ The index captures how far the political distribution is from being bipolar, with political polarization $_{m}=1$ indicating a bipolar political scenario.

To construct these indexes, we use electoral results from the 2005 and 2010 municipal elections. With data from the 2010 elections, estimates could potentially suffer from a reverse causality bias, as the occurrence of electoral violence before the municipal election may have affected voting behavior-and hence indexes of political competition-in a nonrandom way. We therefore rely on the data from the 2005 elections in our benchmark regressions. Nonetheless, we show that results are not significantly affected when political competition is measured using the results of the 2010 municipal elections.

\section{Demobilized Rebels' Fractionalization, Polarization, and Number}

We construct fractionalization (eq. [2]) and polarization (eq. [3]) indexes based on ex-rebels' affiliations. We use data from official registers containing in-

${ }^{22}$ In our sample, $N=2$. Because $\pi_{i}=\left(1-\pi_{j}\right)$, the formula becomes: ethnic frac $=$ $\left(1-\pi_{i}\right) \pi_{i}+\left(1-\pi_{j}\right) \pi_{j}=\left(1-\pi_{i}\right) \pi_{i}+\left(1-\left(1-\pi_{i}\right)\right)\left(1-\pi_{i}\right)=2\left(1-\pi_{i}\right) \pi_{i}$.

${ }^{23}$ In the case of two parties, 1 and 2 , with voting shares $\pi_{1}$ and $\pi_{2}$, such that $\pi_{1}+\pi_{2}=1$, elections are defined as close if $\pi_{1}$ and $\pi_{2}$ are sufficiently close to $50 \%$; i.e., if $\left|0.5-\pi_{1}\right|=\left|0.5-\pi_{2}\right|<\epsilon$. This is equivalent to $\left|\frac{0.5-\pi_{1}}{0.5}\right|<2 \epsilon \Leftrightarrow\left|\frac{0.5-\pi_{1}}{0.5}\right| \pi_{1}+\left|\frac{0.5-\pi_{1}}{0.5}\right|\left(1-\pi_{1}\right)<2 \epsilon \Leftrightarrow\left|\frac{0.5-\pi_{1}}{0.5}\right| \pi_{1}+\left|\frac{0.5-\pi_{2}}{0.5}\right| \pi_{2}<$ $2 \epsilon \Leftrightarrow 1-\sum_{i=1,2}\left|\frac{0.5-\pi_{i}}{0.5}\right| \pi_{i}>1-2 \epsilon$. The left-hand side of the latter inequality is the indicator of polarization proposed by Sterck (2015). Similar results are obtained with the Garcia-Montalvo and Reynal-Querol (2005b) index of ethnic polarization, which consider the quadratic value of the term in the sum rather than its absolute value (table B.9 in the appendix). 
formation on the return of approximately 30,000 combatants from 10 armed groups demobilized between 2004 and 2009. ${ }^{24}$ We also control for the number of demobilized rebels per municipality per 1,000 inhabitants.

Most of the rebels were demobilized from the traditionally Hutu CNDDFDD, led by Nkurunziza, the incumbent president (12,000 demobilized soldiers). ${ }^{25}$ The second-largest group was the FNL-Palipehutu, whose leader is Agathon Rwasa, Nkurunziza's main opponent. The remaining 4,500 demobilized ex-combatants are shared among the remaining six Hutu rebel groups.

\section{Other Covariates}

We compute a median wealth index for each municipality from the household data from the 2010 Demographic and Health Survey (DHS). ${ }^{26}$ The DHS wealth index uses information on the household's ownership of assets (e.g., bicycle and radios), environmental conditions, and housing characteristics (e.g., type of water source, sanitation facilities, materials used for housing construction) and uses a principal components analysis to assign weights to the different components of the index (Rutstein and Johnson 2004). We control for the history of violence experienced by the municipalities from 1997 to 2009 by relying on the Armed Conflict Location \& Event Data (ACLED) data set. ACLED contains records on 2,669 events, among which are battles and attacks against civilians that occurred throughout Burundi from 1997 to 2009 (Raleigh et al. 2010). ${ }^{27}$ Population size comes from the last available census, conducted in 2008 by the Institut de Statistiques et d'Etudes Economiques du Burundi (ISTEEBU).

\section{B. Estimation Method}

Given the count and nonnormal nature characterizing the occurrence of electoral violence, Hilbe (2011) recommends estimating equation (1) with Poisson or negative binomial models. A Poisson distribution assumes that the mean and the conditional variance of the dependent variable are equal. This

\footnotetext{
${ }^{24}$ The National Commission for Demobilization, Reinsertion and Reintegration kindly shared the data.

${ }^{25}$ It should be noted that most of the demobilized soldiers come from the former national army (FAB) and the current national forces of defense (FDN; 13,000 demobilized soldiers). Nevertheless, since FAB did not turn into a political party and its soldiers may be affiliated with a different political group, we exclude these demobilized soldiers when we construct indexes of polarization and fractionalization. Controlling for the demobilization of FAB and FDN does not significantly affect the results (table B.18).

${ }^{26}$ The survey was conducted in 128 municipalities (out of 129). Sampling weights are accounted for.

27 Battles are "violent interaction between two politically organized armed groups at a particular time and location" (Raleigh and Dowd 2016,8). We exclude nonviolent events, riots, and protests.
} 


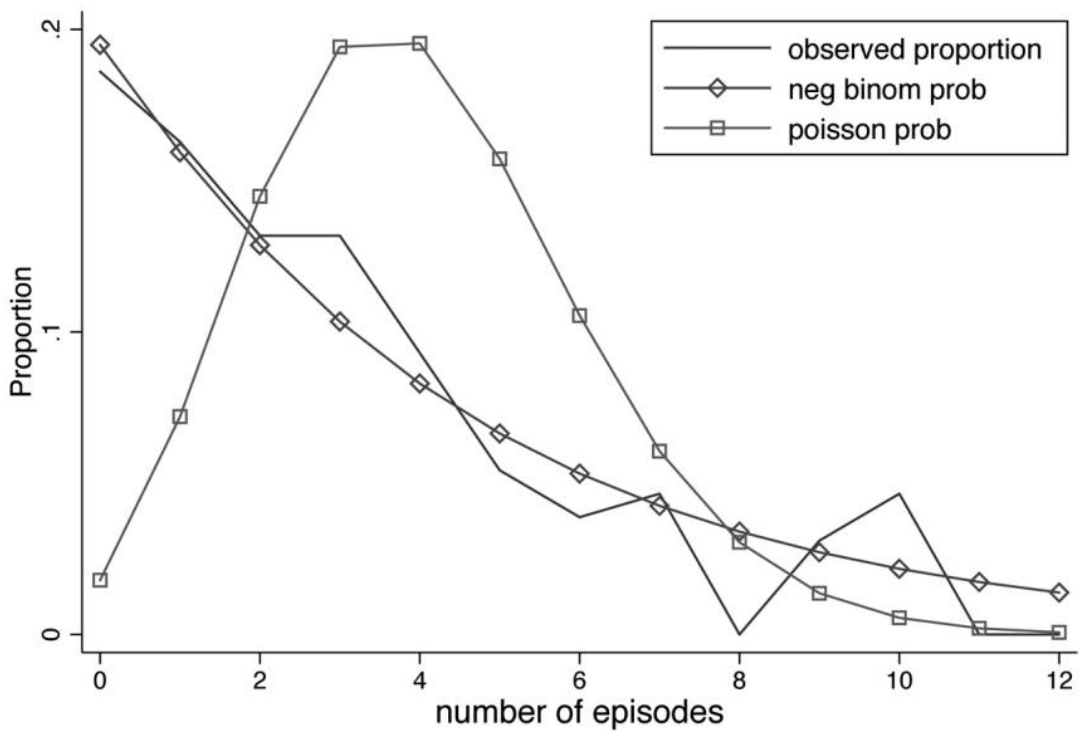

Figure 2. Goodness of fit of negative binomial and Poisson models. A color version of this figure is available online.

assumption does not hold for the distribution of violent episodes. Its conditional variance is 20.41 , which is five times higher than its conditional mean (4.02), indicating overdispersion in the data. This diagnosis is confirmed by $\chi^{2}$ goodness-of-fit tests, which strongly reject the null hypothesis that the data follow a Poisson distribution $(p=.00)$. Given strong overdispersion in the dependent variable, we opt for a negative binomial regression model (Hilbe 2011). The model specification is validated by Pearson's dispersion tests and link tests. Figure 2 plots the distribution of violent episodes against a Poisson distribution and a negative binomial distribution with the same mean and variance. It further confirms how the latter performs better than the former in explaining the data on electoral violence. Ordinary least squares and Poisson estimates are nonetheless presented in the appendix (available online) and give similar results.

We undertake a matching exercise between neighboring municipalities to minimize the risk of omitted variable bias. We do so by constructing a database that identifies each neighborhood of municipalities by a dummy variable, which we then include as fixed effects in the regressions. These geographic, or tight, fixed effects should capture unobserved characteristics common among neighboring municipalities. This approach relies on the assumption that neighboring municipalities are likely to be similar. ${ }^{28}$ This assumption is valid if un-

\footnotetext{
${ }^{28}$ Neighboring is defined as sharing a common border.
} 
observable characteristics are geographically distributed and if borders between municipalities are exogenous enough to ensure no important differences between unobservable characteristics of neighboring municipalities (Huillery 2009).

We rely on three definitions of neighborhood to compute the fixed effects that are included in the model. ${ }^{29}$

\section{All Pairs}

We built a new data set by matching each municipality with each of its neighbors. Municipalities have between two and 10 neighbors (mean $=5.44$ neighbors). ${ }^{30}$ Each pair is identified by a dummy. We then estimate equation (1) by including pair fixed effects. Since municipalities have many neighbors and are neighbors of many other municipalities, standard errors are clustered at three levels (Cameron, Gelbach, and Miller 2011). The first level is the neighborhood. The second level accounts for the fact that each municipality may be the neighbor of several other municipalities. The third level captures the fact that municipalities have duplicates in the sample.

\section{Neighborhood}

We define the neighborhood of municipality as its set of neighbors plus the municipality itself. We built a data set listing all municipalities of the 129 neighborhoods, with each neighborhood then being identified by a dummy variable. This new data set contains 831 lines. ${ }^{31}$ We then reestimate equation (1) by including these neighborhood fixed effects. The estimation of this specification requires clustering standard errors at two levels to account for the fact that municipalities have multiple neighbors and are neighbors of multiple municipalities.

\footnotetext{
${ }^{29}$ Our approach is close to Naidu (2012) and Goldstein and Udry (2008), who take the difference of the variables from the mean of the adjacent administrative units. In our case, the differentiation would lead to negative outcome values, which cannot be fitted by a negative binomial regression.

${ }^{30}$ Data on wealth is missing for one municipality, which has eight neighbors, implying that regressions controlling for wealth and with pair fixed effects rely on 1,388 observations. Pairs of observations in 112 of 702 clusters $(7.98 \%)$ are characterized by the same number of violent episodes. For these observations, electoral violence is fully explained by the fixed effects. The intracluster correlation is not statistically different from 0 , implying that fixed effects do not capture all the variation in the dependent variable.

${ }^{31}$ There are 129 municipalities having, on average, 5.44 neighbors: $129+(5.44 \times 129)=831$. Data on wealth is missing for one municipality, which has eight neighbors, implying that regressions controlling for wealth with neighborhood fixed effects rely on 822 observations. In all neighborhoods, there is variation in the number of violent episodes. The intracluster correlation is not statistically different from 0 , implying that fixed effects capture only a small proportion of the variation in the dependent variable.
} 


\section{Random Pairs}

The third method uses the same sample as the all pairs fixed effects method. However, instead of considering all pairs of neighbors simultaneously, we constituted a subsample of pairs by matching each municipality with one of its neighbors, selected randomly. We then estimate equation (1) using this sample of $2 \times 129$ observations. ${ }^{32}$ To avoid the effect being driven by particular neighborhood designs, we repeat the sampling procedure and reestimate the regression 200 times. We report the average of estimated coefficients and standard errors. As the same municipality can appear within different pairs, we clustered standard errors at the municipal level.

In tables B.23 and B.24 in the appendix, we show that the inclusion of geographic fixed effects improves the balance on observables. We compare regressions of control variables on variables of interest with and without fixed effects matching. The absolute value of regression coefficients either decreases or is not significantly affected by the inclusion of fixed effects. ${ }^{33}$ Even if the balance remains imperfect after fixed effects matching (some coefficients remain significant), which is not surprising given the absence of randomized treatment, these results show that municipalities with different treatment intensity look more similar with geographic fixed effects. ${ }^{34}$

\section{Causal Chain and Bad Controls}

The three hypotheses are related to each other in the context of Burundi. As shown in table 1, most political parties and rebel groups are ethnically rooted, and most parties are issued from demobilized rebel groups. Nevertheless, the three hypotheses capture different aspects of the political environment in $\mathrm{Bu}$ rundi that should be disentangled in the empirical analysis. The correlation between electoral results of former rebel groups and their share of demobilized rebels is high but far from perfect. Many parties have no demobilized ex-combatants, and their ethnic orientations are heterogeneous. This implies that the correlations between our variables of interest are rather limited. For example, the correlation between political fractionalization and the propor-

\footnotetext{
${ }^{32}$ Data on wealth is missing for one municipality, implying that regressions controlling for wealth with random pair fixed effects rely on 128 observations.

${ }^{33}$ The balance is improved with fixed effects (i.e., the absolute value of coefficients is reduced) for $77 \%$ of coefficients tested, although the difference is significant for only $7 \%$ of coefficients. For $23 \%$ of coefficients, the absolute value of coefficients increases but not significantly. While $68 \%$ of coefficients are significant at conventional levels without fixed effects matching, this proportion is reduced to $35 \%$ thanks to fixed effects.

${ }^{34}$ Spatial correlation across municipalities in terms of the quality and composition of their soil and landform can be visualized in figs. C.7 and C.8 in the appendix. Such a geographic correlation further justifies the use of geographic fixed effects.
} 
tion of Hutu at the municipal level is equal to -0.42 . The correlation between political fractionalization and demobilized rebels' fractionalization is only equal to 0.01 and only 0.09 between political polarization and demobilized rebels' polarization (fig. C. 1 in the appendix). The three hypotheses are therefore distinguished in the empirical analysis.

It is interesting to test the three hypotheses simultaneously as well as separately. Testing all hypotheses simultaneously limits the risk of omitted variable bias. However, it may also induce a problem of bad controls (Angrist and Pischke 2008): a variable of interest $X_{i}$ may appear insignificant if another variable included in the regression, $X_{j}$, is in fact a channel of the impact of $X_{i}$ rather than being a primary factor of violence. If hypotheses are tested separately, both variables $X_{i}$ and $X_{j}$ will appear to be significant. In this case, theoretical reasoning is needed to determine whether the correlation between $X_{i}$ and electoral violence when $X_{j}$ is not controlled for is due to omitted variable bias or whether $X_{i}$ is not significant when all hypotheses are tested simultaneously because $X_{j}$ is actually a channel of the impact of $X_{i}$ on electoral violence, that is, a bad control. In what follows, we test the three hypotheses separately and simultaneously and compare regression coefficients across specifications.

We control for past violence and wealth in equation (1). These variables could also be considered as bad controls. Violence during the civil war, for instance, was partly driven by ethnic grievances. If past violence triggered electoral violence in 2010, it could therefore be considered as a channel or a bad control. Likewise, wealth, which could explain electoral violence, may have been affected by ethnic distribution. We therefore face a trade-off: on the one hand, the inclusion of past violence and wealth in the regressions may attenuate the impact of variables of interest; on the other hand, removing these variables from the list of controls could induce an omitted variable bias. We show that the problems from omitted variable bias and bad controls are marginal in our case study. The results do not significantly change when past violence and wealth are included in or removed from the list of controls.

\section{Results}

In Section V.A, we examine whether electoral violence is correlated with ethnic composition, political competition, and the distribution of demobilized rebels. In Section V.B, we study how these factors interact together to favor the emergence of electoral violence.

\section{A. Benchmark Results}

In columns $1-8$ of table 3 , we explore one by one the three hypotheses that may explain why violence spoiled the 2010 elections in Burundi. In columns 9 


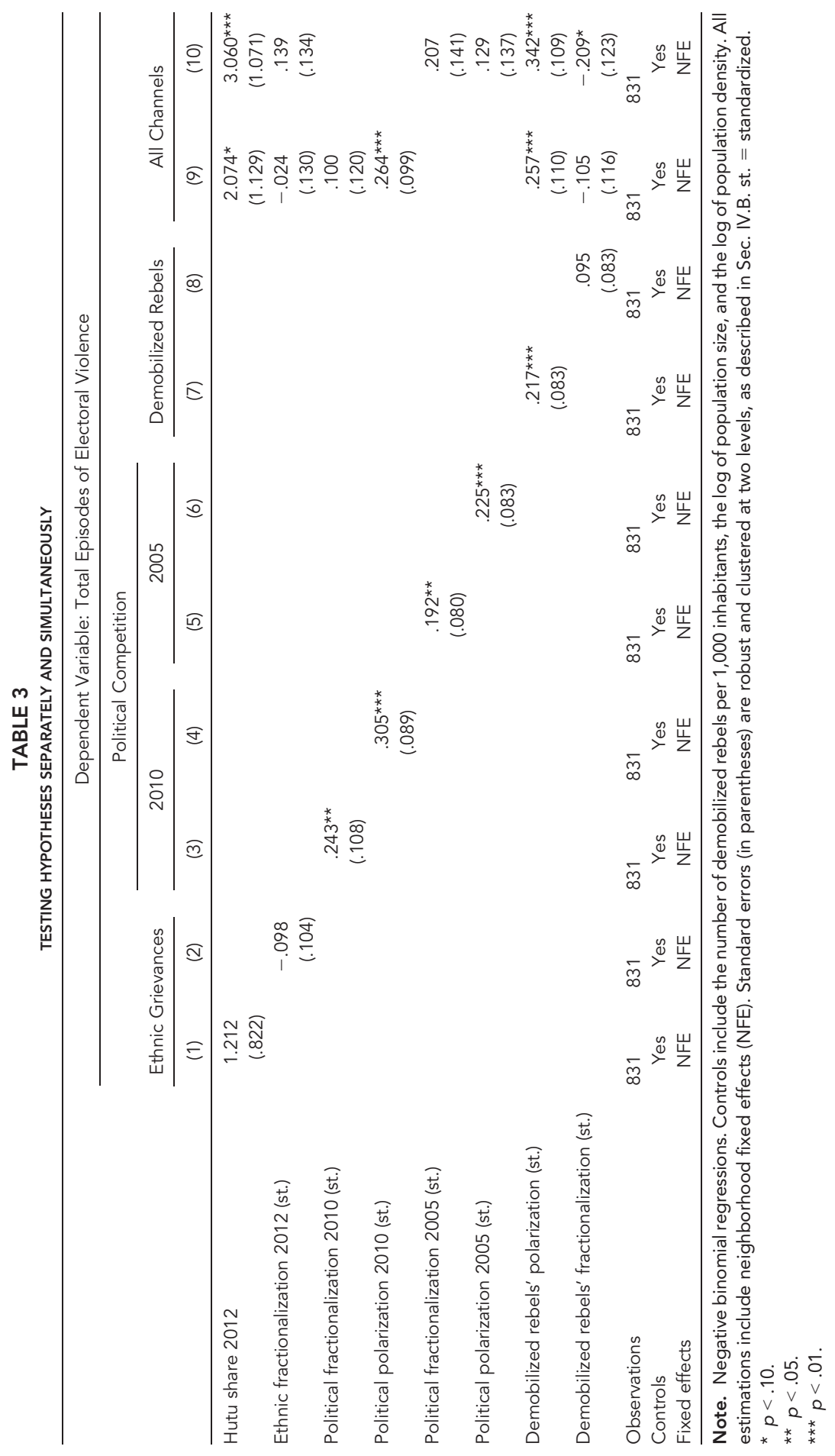

This content downloaded from 163.001.203.194 on January 14, 2020 01:33:11 AM 
and 10 , the three hypotheses are tested simultaneously. ${ }^{35}$ Neighborhood fixed effects are included in these specifications. ${ }^{36}$ Control variables include the number of demobilized combatants, population size, and population density. In table 4, we show that results are robust to the different types of fixed effects. We also show that controlling for past violence and for the wealth index does not significantly change the results, suggesting that the problem of bad controls is marginal for these variables.

In columns 1 and 2 of table 3 , we assess whether the ethnic composition of municipalities is correlated with the occurrence of electoral violence. From column 1, we see that the share of Hutu is positively correlated with electoral violence. The coefficient is large, but the relationship is not significant at conventional levels ( $p=.14$ ). As shown in columns 9 and 10 , the coefficient becomes larger and significant when controlling for political competition. Indeed, the coefficient associated with the proportion of Hutu is likely to be downward biased when political fractionalization is omitted from the list of independent variables, as political fractionalization is positively correlated with electoral violence and negatively correlated with the proportion of Hutu. ${ }^{37}$ Ethnic diversity, measured by ethnic fractionalization, is not correlated with electoral violence.

The relevance of political competition is examined in columns 3-6 of table 3. Given the aforementioned risk of reverse causality, we compare indexes of political competition based on the results of the 2005 and 2010 municipal elections. Both political fractionalization and polarization have a positive and significant effect on electoral violence when they are considered separately. If both indicators are included in the regressions (cols. 9 and 10), the polarization index is significant when political competition is built on 2010 electoral data, while the fractionalization index captures most of the effect when political competition is measured using 2005 electoral data. These ambiguous results can be explained by the multicollinearity between political polarization and fractionalization: both indicators capture the same mechanism in this case

${ }^{35}$ As mentioned in the conceptual framework, these three hypotheses do not provide an exhaustive list of possible channels of electoral violence. As a matter of fact, tables B.1 and B. 15 show that the adjusted $R^{2}$ of ordinary least squares regressions ranges between 0.08 and 0.19 without fixed effects (between 0.21 and 0.33 with fixed effects). Such results show that our hypotheses are not exhaustive and that part of the variation is left unexplained. The $R^{2}$ are nonetheless in line with those of similar papers (see, e.g., Garcia-Montalvo and Reynal-Querol 2005b, in which pseudo $R^{2}$ range between 0.09 and 0.13 ).

${ }^{36}$ For the sake of brevity, we focus on neighborhood fixed effects, as this method leads to more conservative estimates, and no cluster of municipalities is excluded.

${ }^{37}$ In places where the proportion of Hutu is low, the political landscape is more fragmented because both Hutu and Tutsi parties obtain a high share of votes (e.g., in Bujumbura Mairie or in the provinces of Cankuzo and Mwaro). 


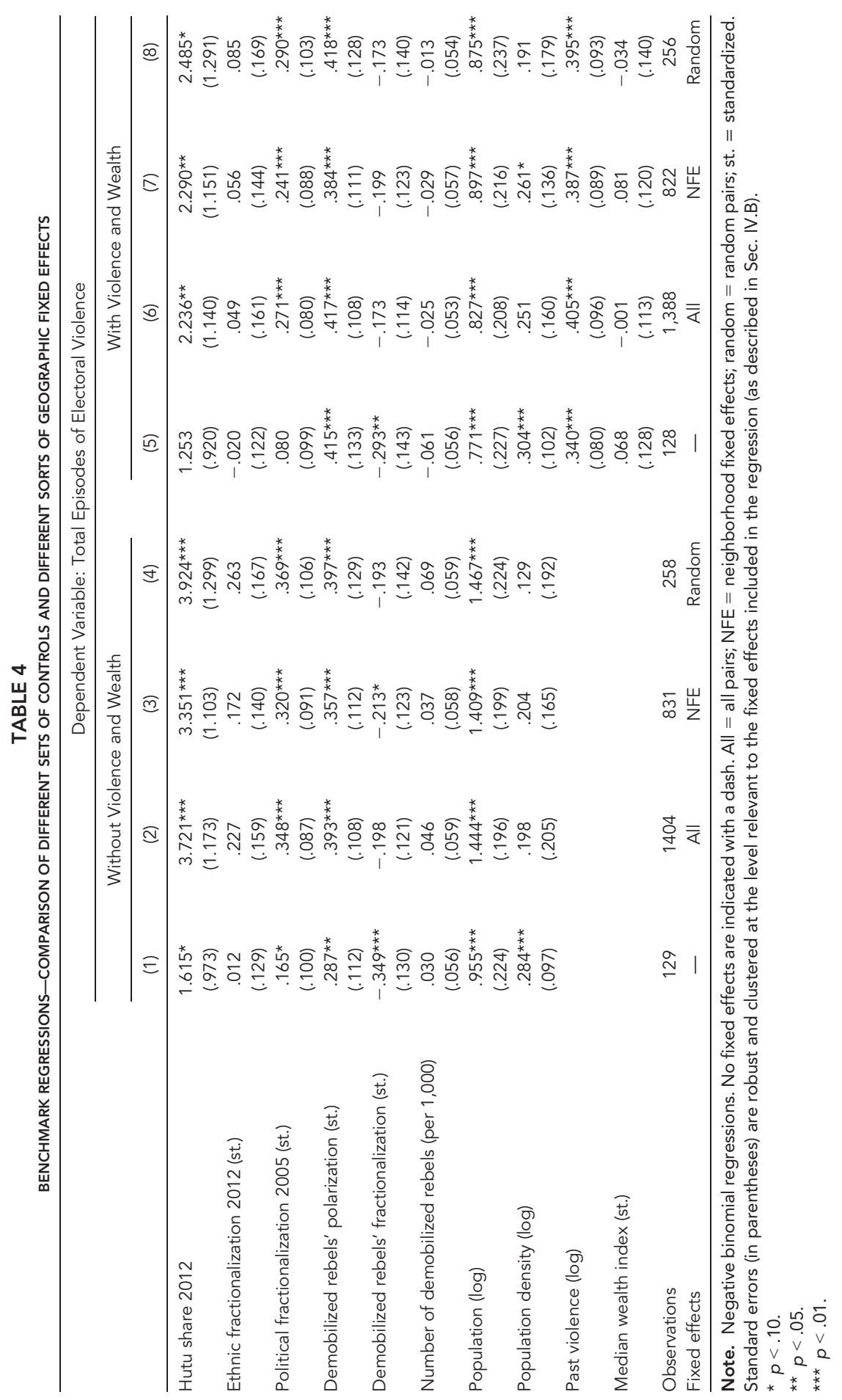


study. Multicollinearity is not surprising given the high correlation between political fractionalization and polarization $(\rho=0.65)$. The two variables are in fact very similar when fractionalization is below 0.6 , which is the case for more than $75 \%$ of the observations (fig. C.2 in the appendix). Interestingly, Alesina et al. (2003) faced the same issue with indexes of ethnic, linguistic, and religious fractionalization and polarization. In what follows, we focus on the political fractionalization index using 2005 data to mitigate multicollinearity and reverse causality. ${ }^{38}$ Similar results are however obtained with the indicator of political polarization and when political competition indicators are constructed using data from the 2010 elections (tables B.2-B.7 in the appendix).

Columns 7 and 8 of table 3 examine whether the distribution of demobilized rebels is correlated with electoral violence in Burundi. The coefficient associated with the polarization index is positive and significant at the $1 \%$ threshold. On the contrary, the coefficient associated with the rebels' fractionalization index is small and not significant. Similar results are obtained when the three hypotheses are tested simultaneously (cols. 9 and 10). Based on column 10, an increase of 1 standard deviation in demobilized rebels' polarization induces a $41 \%$ increase in the number of episodes of electoral violence. ${ }^{39}$ These results show that demobilized rebel groups were more likely to be involved in electoral violence when competing with another group of similar size.

The three hypotheses are jointly tested in table 4 without fixed effects (col. 1), with pair fixed effects (col. 2), with neighborhood fixed effects (col. 3), and with random pairs fixed effects (col. 4). Our findings are stronger when the three hypotheses are jointly tested, thereby minimizing the risk of omitted variable bias. In columns 5-8, the indicators of past violence and median wealth are included in the regressions to minimize omitted variable bias. Results are robust to these alternative specifications.

From table 4, we conclude that ethnic grievances between Hutu and Tutsi did not cause electoral violence in 2010. Instead, violence was more likely to occur in municipalities characterized by a high proportion of Hutu. The coefficients associated with the share of Hutu are positive and large in all specifications. They are significant at the 5\% threshold with all types of fixed effects but not significant at conventional thresholds in a simple cross-section regression when controlling for past violence and the median wealth index.

\footnotetext{
${ }^{38}$ We focus on fractionalization rather than polarization because it is the fractionalization index that captures most of the effect when political competition is measured in 2005. Fractionalization is also negatively correlated with the proportion of Hutu in municipalities; ignoring this indicator may therefore bias downward the coefficient associated the proportion of Hutu.

${ }^{39}$ To interpret the results of the negative binomial regressions in percentage terms, one should take $\exp ^{\beta}-1$.
} 
Based on column 7, our model predicts an increase of about 5.3 violent events between the municipalities characterized by the lowest and the highest proportion of Hutu.

Political competition is also correlated with electoral violence. In table 4, political competition is captured by the index of political fractionalization in 2005. The coefficients associated with political fractionalization are positive and significant at the $1 \%$ level when fixed effects are included in the regression. With fixed effects, the predicted effect of an increase of 1 standard deviation in political fractionalization on electoral violence ranges between $27 \%$ and $45 \%$, depending on the specification.

The coefficients associated with demobilized rebels' polarization are positive and strongly significant in all specifications. The size of the effect is similar to that of political fractionalization. With fixed effects, the predicted effect of an increase of 1 standard deviation in demobilized rebels' polarization on violent events ranges between $43 \%$ and $52 \%$, depending on the specification. This effect is large, representing a four-fold increase in the incidence of events between the lowest- and the highest-polarized municipalities (considering col. 7).

It is important to consider the simultaneous effect of demobilized rebels' fractionalization and polarization since both indicators are constructed based on the distribution of rebel groups. Figure 3 shows the number of predicted violent episodes in each municipality as a function of the number of groups of similar size. ${ }^{40}$ The predicted number of episodes reaches its maximum when there are two groups of former rebels of similar size, that is, when the distribution of demobilized rebels is polarized into two groups.

Importantly, the number of demobilized rebels that returned to the municipality is not associated with electoral violence. We conclude that the number of hard-core supporters does not directly explain the occurrence of electoral violence. Rather, electoral violence is more likely to occur in a municipality characterized by a bipolar distribution of demobilized rebel groups.

Table 4 also provides some evidence that past violence is positively correlated with the electoral violence in 2010. This relationship is in line with reports from the International Crisis Group $(2011,2012,4)$, which points out "rumors circulated from July about the presence of armed groups gradually settling themselves in Kibira forest, a traditional sanctuary for rebel movements." These rumors where confirmed by households that reported looting, clashes between groups, and attacks against the military.

\footnotetext{
${ }^{40}$ Considering $n$ groups of similar size, the index of demobilized rebels' fractionalization as calculated in eq. (2) would collapse to demobilized rebels' fractionalization ${ }_{m}=\sum_{i=1}^{N}\left(1-\pi_{i}\right) \pi_{i}=1-\frac{1}{n}$. Consequently, the projected number of groups of equal size in each municipality is given by $n=\frac{1}{(1-\text { frac })}$.
} 


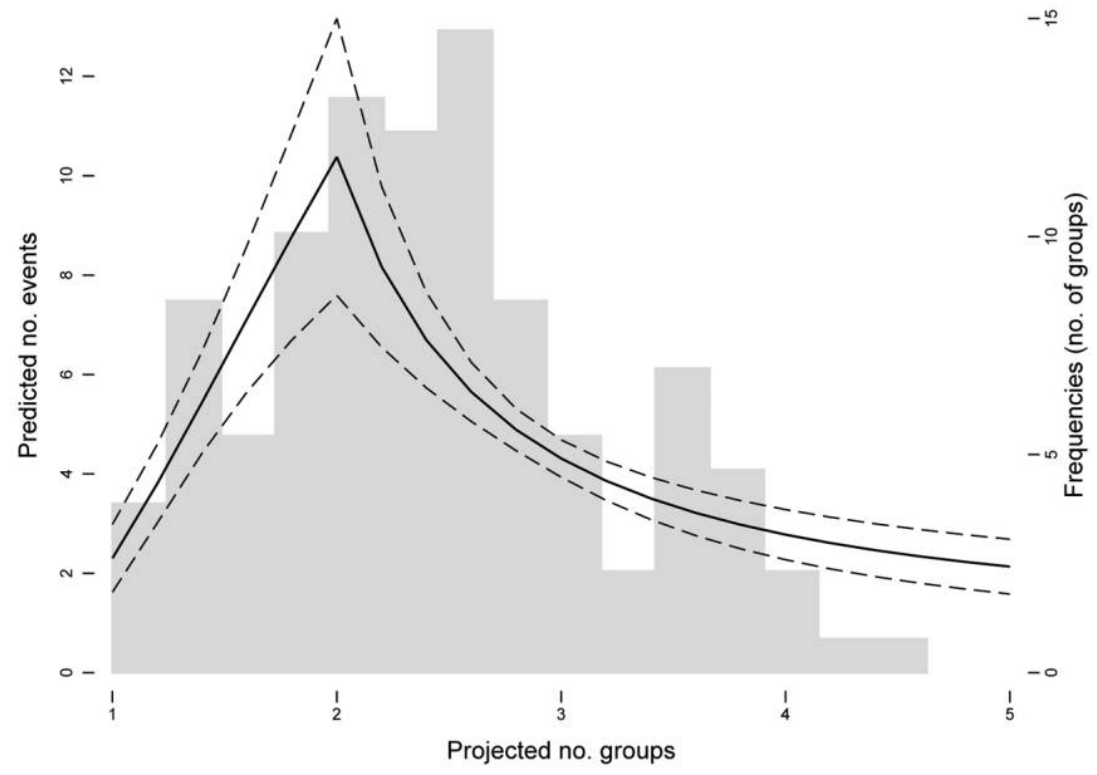

Figure 3. Predicted number of events in a function of the projected number of groups of the same size. Note: this figure is based on the neighborhood fixed effects estimation (table 4, col. 7).

The comparison between tables 3 and 4 shows that ethnic composition, political competition, and the distribution of demobilized rebels are separate factors of violence. The coefficients associated with the share of Hutu, political fractionalization, and demobilized polarization are larger when the three hypotheses are tested simultaneously (although not significantly) and their $p$ values are lower, showing that these factors are not channels of impact or bad controls. The inclusion of past violence (and the index of median wealth) in the list of controls slightly reduces the coefficients associated with the share of Hutu and political fractionalization, although these differences are not statistically significant (table 4). Overall, this suggests that the problem of bad controls is marginal in our study.

\section{B. Heterogeneous Effects}

In this section, we allow for interactions between the variables of interest. ${ }^{41}$ The results are shown in table 5. Marginal and total predicted effects are represented graphically in the appendix (figs. C.3-C.6).

${ }^{41}$ We also tested the interactions between variables of interest and past violence, of which none are significant at conventional thresholds. In table B.8 in the appendix, we conduct the same analysis with political competition constructed using data from the 2010 municipal election. 
TABLE 5

HETEROGENEOUS EFFECTS

\begin{tabular}{|c|c|c|c|c|c|}
\hline & \multicolumn{5}{|c|}{ Dependent Variable: Total Episodes of Electoral Violence } \\
\hline & (1) & (2) & (3) & (4) & (5) \\
\hline Hutu share 2012 & $\begin{array}{l}2.985^{\star \star} \\
(1.214)\end{array}$ & $\begin{array}{l}2.695^{\star \star} \\
(1.220)\end{array}$ & $\begin{array}{l}3.305^{\star \star \star} \\
(1.104)\end{array}$ & $\begin{array}{l}3.661^{\star \star \star} \\
(1.076)\end{array}$ & $\begin{array}{l}2.919 * \star \\
(1.240)\end{array}$ \\
\hline Ethnic fractionalization 2012 (st.) & $\begin{array}{l}.154 \\
(.145)\end{array}$ & $\begin{array}{l}.090 \\
(.156)\end{array}$ & $\begin{array}{l}.192 \\
(.139)\end{array}$ & $\begin{array}{l}.220^{*} \\
(.131)\end{array}$ & $\begin{array}{l}.167 \\
(.154)\end{array}$ \\
\hline Political fractionalization 2005 (st.) & $\begin{array}{l}.311^{\star \star \star} \\
(.091)\end{array}$ & $\begin{array}{c}-.719 \\
(.548)\end{array}$ & $\begin{array}{l}.285^{\star \star \star} \\
(.093)\end{array}$ & $\begin{array}{l}.108 \\
(.109)\end{array}$ & $\begin{array}{r}-.500 \\
(.473)\end{array}$ \\
\hline Demobilized rebels' polarization (st.) & $\begin{array}{c}-.144 \\
(.610)\end{array}$ & $\begin{array}{l}.353^{\star \star \star} \\
(.111)\end{array}$ & $\begin{array}{l}.346^{\star \star \star} \\
(.107)\end{array}$ & $\begin{array}{l}.372^{\star \star \star} \\
(.110)\end{array}$ & $\begin{array}{r}-.058 \\
(.605)\end{array}$ \\
\hline Demobilized rebels' fractionalization (st.) & $\begin{array}{r}-.233^{\star} \\
(.128)\end{array}$ & $\begin{array}{c}-.220^{\star} \\
(.120)\end{array}$ & $\begin{array}{c}-.211^{\star} \\
(.120)\end{array}$ & $\begin{array}{c}-.228^{\star} \\
(.126)\end{array}$ & $\begin{array}{c}-.245^{\star} \\
(.129)\end{array}$ \\
\hline Number of demobilized rebels (per 1,000) & $\begin{array}{l}.034 \\
(.057)\end{array}$ & $\begin{array}{l}.021 \\
(.054)\end{array}$ & $\begin{array}{l}.026 \\
(.057)\end{array}$ & $\begin{array}{l}.097 \\
(.060)\end{array}$ & $\begin{array}{l}.069 \\
(.063)\end{array}$ \\
\hline Population (log) & $\begin{array}{l}1.419^{\star \star \star} \\
(.202)\end{array}$ & $\begin{array}{l}1.434^{\star \star \star} \\
(.204)\end{array}$ & $\begin{array}{l}1.492^{\star \star \star} \\
(.204)\end{array}$ & $\begin{array}{l}1.326^{\star \star \star *} \\
(.199)\end{array}$ & $\begin{array}{l}1.420^{\star \star \star *} \\
(.210)\end{array}$ \\
\hline Population density (log) & $\begin{array}{l}.170 \\
(.176)\end{array}$ & $\begin{array}{l}.181 \\
(.172)\end{array}$ & $\begin{array}{l}.171 \\
(.173)\end{array}$ & $\begin{array}{l}.248 \\
(.143)\end{array}$ & $\begin{array}{l}.178 \\
(.163)\end{array}$ \\
\hline Demobilized rebels' polarization $\times$ Hutu share & $\begin{array}{l}.619 \\
(.761)\end{array}$ & & & & $\begin{array}{l}.514 \\
(.759)\end{array}$ \\
\hline Political fractionalization $\times$ Hutu share & & $\begin{array}{l}1.286^{\star} \\
(.681)\end{array}$ & & & $\begin{array}{l}.741 \\
(.611)\end{array}$ \\
\hline $\begin{array}{l}\text { Demobilized rebels' polarization } \times \text { political } \\
\text { fractionalization }\end{array}$ & & & $\begin{array}{r}-.118^{\star} \\
(.063)\end{array}$ & & $\begin{array}{r}-.089 \\
(.061)\end{array}$ \\
\hline $\begin{array}{l}\text { Demobilized rebels }(\text { per } 1,000) \times \text { political } \\
\text { fractionalization }\end{array}$ & & & & $\begin{array}{l}.127^{\star \star \star} \\
(.046)\end{array}$ & $\begin{array}{l}.113^{\star \star} \\
(.048)\end{array}$ \\
\hline Observations & 831 & 831 & 831 & 831 & 831 \\
\hline Fixed Effects & NFE & NFE & NFE & NFE & NFE \\
\hline
\end{tabular}

Note. Negative binomial regressions. All estimations include neighborhood fixed effects (NFE). Standard errors (in parentheses) are robust and clustered at two levels as described in Sec. IV.B. st. = standardized. ${ }^{*} p<.10$.

$\star * \quad p<.05$

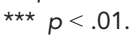

1. Demobilized Rebels' Polarization and Proportion of Hutu

In line with the conceptual framework, it is intuitively plausible that polarization between demobilized rebel groups is a better predictor of electoral violence in pro-Hutu municipalities. The expected return from violence should indeed be higher in pro-Hutu municipalities as the Hutu are the majority and hence more likely to rule the country after the elections. We test this hypothesis by interacting demobilized rebels' polarization with the proportion of Hutu. We expect the marginal impact of the demobilized rebels' polarization index to be close to zero in Tutsi municipalities and then to increase with the proportion of Hutu. Similarly, the marginal impact of the proportion of Hutu should be close to zero in municipalities that are not polarized and increase 
with the demobilized rebels' polarization index. Results from column 1 of table 5 confirm this intuition, although the coefficient of the interaction term is not significant at conventional thresholds. Demobilized rebels' polarization and the proportion of Hutu seem to be complementary explanations of electoral violence.

\section{Political Fractionalization and Proportion of Hutu}

A similar reasoning applies to the interaction between political fractionalization and the proportion of Hutu. The Hutu are the majority and have the most to gain or lose from electoral competition. It is therefore likely that the correlation between political competition and electoral violence will be higher in pro-Hutu municipalities and lower in pro-Tutsi municipalities. Results confirm this intuition: the coefficient of the interaction term in column 2 of table 5 is positive and significant. Electoral violence is particularly high in Hutu strongholds where political competition is high, confirming the intra-Hutu dimension of postwar electoral competition.

\section{Demobilized Rebels' Polarization and Political Fractionalization}

In column 3 of table 5 , we investigate the extent to which the interaction between demobilized rebels' polarization and political fractionalization determines electoral violence. We have no prior assumptions about the sign of the interaction term. It could be positive if both factors are jointly required to generate electoral violence or negative if only one of these factors is sufficient for causing violence. Results show that the coefficient associated with the interaction term is negative and significant. As shown in figure C. 5 in the appendix, the total predicted effect of these two variables is similar if only demobilized rebels' polarization is high, if only political fractionalization is high, or if both variables are high. Only one of these conditions is needed to increase the prevalence of electoral violence.

\section{Number of Demobilized Rebels and Political Fractionalization}

The literature suggests that the presence of specialists in violence or hard-core supporters, such as demobilized rebels, is likely to increase the return from violent campaigning (Chaturvedi 2005; Collier and Vicente 2012). We therefore test whether the number of demobilized rebels and political competition are complementary explanations for electoral violence. In column 4 of table 5, the coefficient associated with this interaction is positive and significant. The presence of demobilized rebels increases the likelihood of violence in places where political competition is intense. 


\section{Discussion}

In this section, we further discuss the results and put them in perspective with the mechanisms identified in the conceptual framework. We then discuss whether electoral violence in 2010 is different from other types of violence. Finally, we show that our results are robust to alternative specifications.

\section{A. Reconciling Theoretical and Empirical Evidence}

While the economic literature points to ethnic grievances in explaining violence, our results show that this explanation is not relevant for explaining electoral violence during the 2010 electoral process in Burundi. Violence rather emerged as a result of tensions between political parties and between demobilized rebel groups in pro-Hutu areas. As explained in the conceptual framework, the stakes of the election were indeed higher for Hutu parties, thereby generating higher incentives to engage in violent campaigning. Such outcomes were also described in the recent literature on the political landscape in $\mathrm{Bu}$ rundi, confirming the evolution from interethnic conflict to an intra-Hutu competition for power. ${ }^{42}$ Palmans (2012) writes, "unlike in 1993, electoral competition [in 2010] is no longer dominated by ethnic rivalry." Similarly, Vandeginste $(2014,268)$ reports that "there is general agreement ... that the 2010 Burundian elections were no longer a matter of primarily ethnic competition-which is quite an achievement in a country torn apart by politico-ethnic strife for decades."

We also find that high political competition between parties increased the likelihood of electoral violence. Contrary to the theoretical predictions of Chaturvedi (2005) and Collier and Vicente (2012), illicit campaigning was not a strategy of weak parties against the strong ones during the 2010 elections in Burundi. Our results rather show that electoral violence emerged where electoral competition was tight, in line with the theoretical model of Sterck (2015). The effect of political competition is stronger in Hutu-dominated municipalities, showing that ethnic power sharing, which has been institutionalized in Burundi through the Arusha agreements and the 2005 constitution, "contributed to reducing the ethnic divide in Burundian society which today is shaken by tensions based on what are essentially political cleavages within the Hutu majority" (International Crisis Group 2011).

Finally, we find that hard-core supporters, or specialists in violence, played a role in sparking violence, as suggested by Chaturvedi (2005) and Collier and Vicente (2012). Our empirical analysis identifies two mechanisms. First, electoral violence is more likely to emerge in the presence of two main groups of

\footnotetext{
${ }^{42}$ See, e.g., International Crisis Group (2011), Vandeginste (2011, 2014), or Palmans (2012).
} 
demobilized rebels of similar size. Second, the presence of numerous demobilized rebels amplifies the impact of political competition on violence. The instability due to the presence of demobilized rebels and their association with parties has been reported by observers and nongovernmental organizations on the ground. Human Rights Watch $(2010,13)$ reports, "The presence of partisan youth groups adds to political volatility. A number of parties have made significant efforts to recruit demobilized combatants, raising concerns that such youth could easily be manipulated into carrying out acts of violence." In addition, many demobilized combatants were the victims of violence (Amatora Mu Mahoro 2010; Human Rights Watch 2012).

In line with the work of Horowitz (1985), we find that tensions between demobilized rebel groups are better captured by an indicator of polarization between demobilized groups than by an indicator of fractionalization. This is also in accordance with Esteban, Mayoral, and Ray (2012b, abstract), who conclude that polarization is more important "when the winners enjoy a public prize (such as political power or religious hegemony)." Our study is not as conclusive about the relative performance of political fractionalization and polarization indexes. ${ }^{43}$

\section{B. Is Electoral Violence Different from Other Types of Violence?}

To answer this question, we undertake a falsification exercise in which we replace the dependent variable, electoral violence, by other variables that are related in nature but that are not expected to be affected by the same regressors of interest. Results are presented in table 6 . This exercise does not aim to uncover causal relationships but rather to provide suggestive evidence that electoral violence is different from other types of violence.

In columns 1 and 2, the dependent variables are respectively the attacks against civilians and battles that occurred between 1997 and 2006, as recorded in the ACLED data. ${ }^{44}$ In column 3, we used data from the 2010 DHS survey to compute the proportion of individuals who think that domestic violence is justified in at least one of the five following situations: the wife goes out without telling her husband, she neglects children, she argues with her husband, she refuses to have sex with him, or she burns the food. ${ }^{45}$ The last two falsi-

\footnotetext{
${ }^{43}$ As explained in Sec. V, this is due to the high degree of multicollinearity between these two indicators in the context of Burundi. Interestingly, Alesina et al. (2003) encountered the same problem when studying the effects of ethnic, linguistic, and religious heterogeneity on the quality of institutions and growth.

${ }^{44}$ Battles are defined as "a violent interaction between two politically organized armed groups at a particular time and location” (Raleigh and Dowd 2016, 8).

${ }^{45}$ Results are available for 128 out of 129 municipalities.
} 
TABLE 6

FALSIFICATION TESTS

\begin{tabular}{|c|c|c|c|c|c|}
\hline & $\begin{array}{c}\text { Attacks } \\
\text { Civilians } \\
\text { (1) }\end{array}$ & $\begin{array}{l}\text { Battles } \\
\text { (2) }\end{array}$ & $\begin{array}{c}\text { Domestic } \\
\text { Violence } \\
\text { (3) }\end{array}$ & $\begin{array}{l}\text { Fearing } \\
\text { Crime } \\
\text { (4) }\end{array}$ & $\begin{array}{l}\text { Crime } \\
\text { Issue } \\
(5)\end{array}$ \\
\hline Hutu share 2012 & $\begin{array}{l}.061 \\
(.993)\end{array}$ & $\begin{array}{c}1.997 \\
(1.317)\end{array}$ & $\begin{array}{l}.233 \\
(.344)\end{array}$ & $\begin{array}{c}1.140 \\
(1.105)\end{array}$ & $\begin{array}{c}-.561 \\
(.908)\end{array}$ \\
\hline Ethnic fractionalization 2012 (st.) & $\begin{array}{l}.087 \\
(.112)\end{array}$ & $\begin{array}{l}.409^{\star \star \star} \\
(.117)\end{array}$ & $\begin{array}{l}.052 \\
(.043)\end{array}$ & $\begin{array}{c}-.027 \\
(.124)\end{array}$ & $\begin{array}{c}-.183^{\star} \\
(.100)\end{array}$ \\
\hline Political fractionalization 2005 (st.) & $\begin{array}{l}.185^{\star} \\
(.097)\end{array}$ & $\begin{array}{l}.025 \\
(.131)\end{array}$ & $\begin{array}{c}-.051^{\star \star} \\
(.021)\end{array}$ & $\begin{array}{r}-.160 * \\
(.090)\end{array}$ & $\begin{array}{l}.177^{\star \star} \\
(.079)\end{array}$ \\
\hline Demobilized rebels' polarization (st.) & $\begin{array}{c}-.071 \\
(.093)\end{array}$ & $\begin{array}{l}.167 \\
(.115)\end{array}$ & $\begin{array}{l}.006 \\
(.026)\end{array}$ & $\begin{array}{c}-.033 \\
(.124)\end{array}$ & $\begin{array}{l}.120 \\
(.074)\end{array}$ \\
\hline Demobilized rebels' fractionalization (st.) & $\begin{array}{c}-.120 \\
(.104)\end{array}$ & $\begin{array}{c}-.158 \\
(.131)\end{array}$ & $\begin{array}{l}.001 \\
(.026)\end{array}$ & $\begin{array}{c}-.018 \\
(.095)\end{array}$ & $\begin{array}{c}-.051 \\
(.095)\end{array}$ \\
\hline $\begin{array}{l}\text { Number of demobilized rebels } \\
\text { (per } 1,000 \text { ) }\end{array}$ & $\begin{array}{c}.079 \\
(.044)\end{array}$ & $\begin{array}{l}.118^{\star \star \star} \\
(.045)\end{array}$ & $\begin{array}{c}.013 \\
(.011)\end{array}$ & $\begin{array}{l}.029 \\
(.031)\end{array}$ & $\begin{array}{c}.000 \\
(.023)\end{array}$ \\
\hline Population (log) & $\begin{array}{l}1.725^{\star \star \star} \\
(.184)\end{array}$ & $\begin{array}{l}1.687^{\star \star \star} \\
(.198)\end{array}$ & $\begin{array}{c}.043 \\
(.048)\end{array}$ & $\begin{array}{l}-.415^{\star \star \star} \\
(.155)\end{array}$ & $\begin{array}{l}.205 \\
(.163)\end{array}$ \\
\hline Population density (log) & $\begin{array}{r}-.052 \\
(.136)\end{array}$ & $\begin{array}{c}-.119 \\
(.170)\end{array}$ & $\begin{array}{c}-.021 \\
(.059)\end{array}$ & $\begin{array}{c}-.024 \\
(.185)\end{array}$ & $\begin{array}{c}-.167^{\star} \\
(.098)\end{array}$ \\
\hline Observations & 779 & 779 & 822 & 725 & 725 \\
\hline Fixed effects & NFE & NFE & NFE & NFE & NFE \\
\hline
\end{tabular}

Note. Negative binomial regressions. The number of demobilized is by municipality of origin in cols. 1 and 2 and by municipality of return in cols. $3-5$. Attacks against civilians and battles aggregate all ACLED records by type between 1997 and 2009. All estimations include neighborhood fixed effects (NFE). Standard errors (in parentheses) are robust and clustered at two levels, as described in Sec. IV.B. st. = standardized.

$* p<.10$.

** $p<.05$.

$\star * \star \quad p<.01$.

fication tests used proxies of crime prevalence based on the 2012 Afrobarometer survey. The first indicator measures how often households have feared crime in their own house. ${ }^{46}$ The second indicator is the proportion of people who have reported crime and security as among the three most important problems in Burundi. ${ }^{47}$

Electoral violence differs from other types of violence. Demobilized rebels' polarization is never significantly correlated with the five dependent variables. Contrary to our benchmark results, ethnic fractionalization is strongly correlated with battles, in line with the literature on ethnic grievances and civil war (Blattman and Miguel 2010). The relationship between political fractionalization and other types of violence is ambiguous. The coefficient associated with

\footnotetext{
${ }^{46}$ Possible responses are never, just once or twice, a few times, many times, or always. To construct the proxy for crime, we created a dummy variable equal to 1 if they already feared crime at least a few times. Results are robust to the alternative definition measuring the proportion of people who had feared crime at least once (not shown).

${ }^{47}$ Only 111 municipalities were surveyed in the Afrobarometer.
} 
political fractionalization is positive and significant for attacks against civilians and perception of criminality and negative and significant for domestic violence. Overall, these regressions suggest that the determinants of electoral violence are different, particularly regarding the role played by demobilized groups and the absence of relationship with ethnic fragmentation.

\section{Are the Results Robust?}

We further tested the robustness of our results to numerous specifications. We estimated our model with ordinary least squares, Poisson, and negative binomial estimation methods, with three sorts of geographic fixed effects, with alternative vectors of covariates, without outliers, with standard errors adjusted for spatial correlation following Conley (1999), and controlling for spatial dependence. Our results are robust to these alternative estimation strategies. In addition, placebo tests suggest that our results are not driven by the specific nature of our variable of interest. The description of these tests and their results are presented in Section A of the appendix. We further show that results are unlikely to be driven by unobservable characteristics of municipalities.

\section{Concluding Remarks}

In the last four decades, $80 \%$ of elections in sub-Saharan Africa suffered from violence, bribery, intimidation, or inequitable government interference (Bishop and Hoeffler 2014). Using a unique data set on electoral violence in Burundi in 2010 , we tested whether electoral violence is driven by (1) ethnic composition and ethnic grievances, (2) political competition, or (3) the presence and distribution of demobilized combatants. Understanding the causes of electoral misconduct in Burundi is of crucial importance for the stability of the Great Lake region.

The nature of our research question made a randomized controlled trial virtually impossible. To minimize the risk of bias, our identification strategy exploits variations between neighboring municipalities, relying on the fact that these are more likely to have similar unobserved characteristics. We show that electoral violence was more prevalent in municipalities with two equally large groups of demobilized rebels (an increase of 1 standard deviation in polarization among rebel groups leads to a $43 \%-52 \%$ increase in violent events, depending on the specification) and characterized by a fierce political competition (an increase of 1 standard deviation in political fractionalization leads to an increase in violent events ranging between $27 \%$ and $45 \%$, depending on the specification). The latter effect is stronger in municipalities with numerous former rebels. Politicians willing to seize power through illicit means seem to have exploited their former allegiances with demobilized rebels to commit vi- 
olence. Interestingly, cleavages between ethnic groups, which were the main cause of violence in postindependence Burundi, did not fuel electoral violence in 2010. Violent campaigning was more rife in municipalities populated by a high proportion of Hutu.

The findings of this study suggest several important avenues for future research. First, more theoretical work is needed to understand the determinant of electoral violence. In particular, the models of Chaturvedi (2005) and Collier and Vicente (2012) should be extended to meet our empirical findings: rather than being a desirable strategy of the weakest parties, electoral violence in Burundi emerged in places where political competition was tight. Second, empirical research should be conducted to test the external validity of our findings and to distinguish different types of electoral malpractices. Future analysis should also determine when intimidation and violence are used as electoral tools and when they are the mere consequence of frustrations that flare up when tensions run high during elections. Finally, more research is necessary to understand how prevention campaigns could successfully reduce the risk of electoral violence. Following our study, programs specifically targeted at demobilized combatants should be further evaluated.

\section{References}

Alesina, A., R. Baqir, and W. Easterly. 1999. "Public Goods and Ethnic Divisions." Ouarterly Lournal of Economics 114, no. 4:1243-84.

Alesina, A., A. Devleeschauwer, W. Easterly, S. Kurlat, and R. Wacziarg. 2003. "Fractionalization." Lournal of Economic Growth 8, no. 2:155-94.

Amatora Mu Mahoro. 2010. Rapport final: Système de Monitoring des Principes Démocratiques et de Prévention de la Violence Électorale. Washington, DC: International Foundation for Electoral Systems.

Angrist, J., and J.-S. Pischke. 2008. Mostly Harmless Econometrics: An Empiricist's Companion. Princeton, NJ: Princeton University Press.

Annan, J., C. Blattman, D. Mazurana, and K. Carlson. 2011. "Civil War, Reintegration, and Gender in Northern Uganda." Lournal of Conflict Resolution 55, no. 6: 877-908.

Berman, E., M. Callen, C. Gibson, and J. Long. 2014. "Election Fairness and Government Legitimacy in Afghanistan.” NBER Working Paper no. 19949, National Bureau of Economic Research, Cambridge, MA.

Bishop, S., and A. Hoeffler. 2014. "Free and Fair Elections-A New Database." CSAE Working Paper no. 2014-14, Centre for the Study of African Economies, University of Oxford, Oxford.

Blattman, C., and E. Miguel. 2010. "Civil War." Lournal of Economic Literature 48, no. 1:3-57.

Brancati, D., and J. Snyder. 2012. "Time to Kill: The Impact of Election Timing on Postconflict Stability." Lournal of Conflict Resolution 57, no. 5:822-53. 
Cameron, C., J. Gelbach, and D. Miller. 2011. "Robust Inference With Multiway Clustering." Iournal of Business \& Economic Statistics 29, no. 2:238-49.

Chaturvedi, A. 2005. "Rigging Elections With Violence." Public Choice 125, nos. 12:189-202.

Chauvet, L., and P. Collier. 2009. "Elections and Economic Policy in Developing Countries." Economic Policy 24, no. 59:509-50.

Collier, P., and A. Hoeffler. 2015. "Do Elections Matter for Economic Performance?" Oxford Bulletin of Economics and Statistics 77, no. 1:1-21.

Collier, P., and P. Vicente. 2012. "Violence, Bribery, and Fraud: the Political Economy of Elections in Sub-Saharan Africa." Public Choice 153, nos. 1-2:117-47.

- 2014. "Votes and Violence: Evidence from a Field Experiment in Nigeria." Economic Iournal 124, no. 574:327-55.

Conley, T. G. 1999. "GMM Estimation with Cross Sectional Dependence.” Iournal of Econometrics 92, no. 1:1-45.

D’Aoust, O., O. Sterck, and P. Verwimp. 2016. "Who Benefited from Burundi's Demobilization Program?" World Bank Economic Review, http://documents.world bank.org/curated/en/416181467127793026/pdf/WPS7732.pdf.

Dercon, S., and R. Gutiérrez-Romero. 2012. "Triggers and Characteristics of the 2007 Kenyan Electoral Violence.” World Development 40, no. 4:731-44.

Dupas, P., and J. Robinson. 2010. "Coping with Political Instability: Micro Evidence from Kenya's 2007 Election Crisis." American Economic Review 100, no. 2: $120-4$.

- 2012. "The (Hidden) Costs of Political Instability: Evidence from Kenya's 2007 Election Crisis." Iournal of Develomment Economics 99, no. 2:314-329.

Easterly, W., and R. Levine. 1997. "Africa's Growth Tragedy: Policies and Ethnic Divisions." Ouarterlv Journal of Economics 112, no. 4:1203-50.

Eifert, B., E. Miguel, and D. Posner. 2010. "Political Competition and Ethnic Identification in Africa." American Iournal of Political Science 54, no. 2:494-510.

Ellman, M., and L. Wantchekon. 2000. "Electoral Competition under the Threat of Political Unrest." Ouarterly Iournal of Economics 115, no. 2:499-531.

Esteban, J., L. Mayoral, and D. Ray. 2012a. "Ethnicity and Conflict: An Empirical Study." American Economic Review 102, no. 4:1310-42.

- 2012b. "Ethnicity and Conflict: Theory and Facts." Science 336, no. 6083: 858-65.

Esteban, J., and D. Ray. 2008. "Polarization, Fractionalization and Conflict." Iournal of Peace Research 45, no. 2:163-82.

. 2011. "Linking Conflict to Inequality and Polarization." American Economic Review 101:1345-74.

Fafchamps, M., and P. Vicente. 2013. "Political Violence and Social Networks: Experimental Evidence from a Nigerian Election." Iournal of Development Economics 101, no. $1: 27-48$.

Garcia-Montalvo, J., and M. Reynal-Querol. 2005a. "Ethnic Diversity and Economic Development." Iournal of Development Economics 76, no. 2:293-323.

- 2005b. "Ethnic Polarization, Potential Conflict and Civil Wars." American Economic Review 95, no. 3:796-816. 
Gilligan, M., E. Mvukiyehe, and C. Samii. 2013. "Reintegrating Rebels into Civilian Life: Quasi-Experimental Evidence from Burundi." Iournal of Conflict Resolution 57, no. 4:598-626.

Goldstein, M., and C. Udry. 2008. "The Profits of Power: Land Rights and Agricultural Investment in Ghana.” Iournal of Political Economy 116, no. 6:981-1022.

Goose, S., and F. Smyth. 1994. "Arming Genocide in Rwanda." Foreion Affairs 73:86.

Gutiérrez-Romero, R. 2012. "An Inquiry into the Use of Illegal Electoral Practices and Effects of Political Violence." CSAE Working Paper no 2012-16, Centre for the Study of African Economies, University of Oxford, Oxford.

Hausman, J. 2001. "Mismeasured Variables in Econometric Analysis: Problems from the Right and Problems from the Left." Iournal of Economic Perspectives 15, no. 4:57-67.

Hegre, H., T. Ellingsen, S. Gates, and N.-P. Gleditsch. 2001. "Toward a Democratic Civil Peace? Democracy, Political Change, and Civil War, 1816-1992.” American Political Science Review 95, no. 1:33-48.

Helbig de Balzac, H., B. Ingelaere, and S. Vandeginste. 2011. "Voting Practices and Voters Political Thinking during the 2010 Burundi Elections." IOB Discussion Paper no. 2011.06, Institute of Development Policy (IOB), Universiteit Antwerpen.

Henderson, E., and J. Singer. 2000. "Civil War in the Post-Colonial World, 194692." Iournal of Peace Research 37, no. 3:275-99.

Hilbe, J. 2011. Negative Binomial Regression. Cambridge: Cambridge University Press. Horowitz, D. 1985. Ethnic Groups in Conflict. Oakland, CA: University of California Press.

Huillery, E. 2009. "History Matters: The Long-Term Impact of Colonial Public Investments in French West Africa." American Economic Journal: Applied Economics 1, no. 2:176-215.

Human Rights Watch. 2010. "We'll Tie You Up and Shoot You": Lack of Accountability for Political Violence in Burundi. New York: Human Rights Watch.

- 2012. "You Will Not Have Peace While You Are Living": The Escalation of Political Violence in Burundi. New York: Human Rights Watch.

Humphreys, M., and J. Weinstein. 2007. “Demobilization and Reintegration.” Iournal of Conflict Resolution 51, no. 4:531-67.

International Crisis Group. 2011. "Burundi: From Electoral Boycott to Political Impasse.” Africa Report no. 169. International Crisis Group, Brussels.

_. 2012. "Burundi: Bye-Bye Arusha?” Africa Report no. 192. International Crisis Group.

Kudamatsu, M. 2012. "Has Democratization Reduced Infant Mortality in SubSaharan Africa? Evidence From Micro Data." Iournal of European Economic Association 10, no. 6:1294-317.

Lemarchand, R. 2009. The Dynamics of Violence in Central Africa. Philadelphia: University of Pennsylvania Press.

Mamdani, M. 2001. When Victims Become Killers: Colonialism, Nativism, and the Genocide in Rwanda. Princeton, NJ: Princeton University Press.

Naidu, S. 2012. "Suffrage, Schooling and Sorting in the Post-Bellum U.S. South." NBER Working Paper no. 18129, National Bureau of Economic Research, Cambridge, MA. 
NDI. 2014. Monitoring and Mitigating Electoral Violence Through Nonpartisan Citizen Election Observation. Washington, DC: National Democratic Institute.

Omotola, S. 2010. "Explaining Electoral Violence in Africa’s 'New' Democracies." African Journal on Conflict Resolution 10, no. 3:51-73.

Palmans, E. 2012. Burundi's 2010 Elections: Democracy and Peace At Risk? Brussels: European Centre for Electoral Support.

Prunier, G. 2009. From Genocide to Continental War. The Congolese Conflict and the Crisis in Contemporary Africa. London: Hurst.

Raleigh, C., and C. Dowd. 2016. Armed Conflict Location and Event Data Project (ACLED) Codebook 2016. https://www.acleddata.com/wp-content/uploads /2016/01/ACLED_Codebook_2016.pdf.

Raleigh, C., A. Linke, H. Hegre, and J. Karlsen. 2010. "Introducing ACLEDArmed Conflict Location and Event Data." Lournal of Peace Research 47, no. 5: $1-10$.

Robinson, J., and R. Torvik. 2009. “The Real Swing Voter's Curse.” American Economic Review 99, no. 2:310-5.

Rutstein, S.-O., and K. Johnson. 2004. "The DHS Wealth Index.” DHS Comparative Report no. 6. Calverton, MD: ORC Macro.

Schneider, G., and N. Wiesehomeier. 2008. "Rules That Matter: Political Institutions and the Diversity-Conflict Nexus." Iournal of Peace Research 45, no. 2: 183-203.

Sterck, O. 2015. "Fighting for Votes: Theory and Evidence on the Causes of Electoral Violence." CSAE Working Paper no. 2015-19, Centre for the Study of African Economies, University of Oxford, Oxford.

Van Acker, T. 2015. "Understanding Burundi's Predicament." Africa Policy Briefs 2015:1-10.

Vandeginste, S. 2011. "Power-Sharing as a Fragile Safety Valve in Times of Electoral Turmoil: The Costs and Benefits of Burundi's 2010 Elections." Iournal of Modern African Studies 49, no. 2:315-35.

- 2012. "Burundi's Truth and Reconciliation Commission: How to Shed Light on the Past while Standing in the Dark Shadow of Politics?" International Lournal of Transitional Justice 6, no. 2:355-65.

- 2014. "Governing Ethnicity after Genocide: Ethnic Amnesia in Rwanda versus Ethnic Power-Sharing in Burundi." Iournal of Eastern African Studies 8, no. 2: 263-77.

2015. "Burundi's Electoral Crisis-Back to Power-Sharing Politics as Usual?" African Affairs 114, no. 457:624-36.

Verwimp, P., and T. Bundervoet. 2009. "Civil War and the Welfare of Extended Households: Evidence from Longitudinal Data from Burundi." HiCN Working Paper no. 70, Households in Conflict Network, Brighton, England.

Wilkinson, S. 2004. Votes and Violence: Electoral Competition and Ethnic Riots in India. Cambridge: Cambridge University Press.

World Bank Group. 2004. Emergency Demobilization and Transitional Reintegration in Burundi. Washington, DC: World Bank Publications. 